\title{
Combustible Contents in Buildings
}

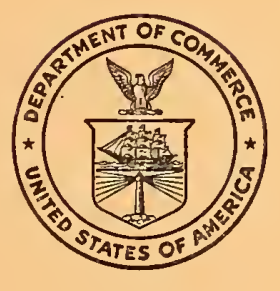

United States Department of Commerce

National Bureau of Standards

Building Materials and Structures Report 149 


\section{BUILDING MATERIALS AND STRUCTURES REPORTS}

On request, the Superintendent of Documents, U. S. Government Printing Office, Washington 25, D. C., will place your name on a special mailing list to receive notices of new reports in this series as soon as they are issued. There will be no charge for receiving such notices.

If 100 copies or more of any report are ordered at one time, a discount of 25 percent is allowed. Send all orders and remittances to the Superintendent of Documents, $U$. S. Government Printing Office, Washington $25, D$. C.

The following publications in this series are available by purchase from the Superintendent of Documents at the prices indicated:

BMS1

BMS2

BMS3

BMS4

BMS5

BMS6

BMS7

BMS8

BMS9

BMS10

BMS11

BMS12

BMS13

BMS14

BMS15

BMS16

BMS17

BMS18

BMS19

BMS20

BMS21

BMS22

BMS23

BMS24

BMS25

BMS26

BMS27

BMS28

BMS29

BMS30

BMS31

BMS32

BMS33

BMS34

BMS35

BMS36

Research on Building Materials and Structures for Use in Low-Cost Housing -...-..-

Methods of Determining the Structural Properties of Low-Cost House Constructions.

Suitability of Fiber Insulating Lath as a Plaster Base

Accelerated Aging of Fiber Building Boards

Structural Properties of Six Masonry Wall Constructions._.........

Survey of Roofing Materials in the Southeastern States -

Water Permeability of Masonry Walls

Methods of Investigation of Surface Treatment for Corrosion Protection of Steel

Structural Properties of the Insulated Steel Construction Co.'s "Frameless-Steel" Constructions for Walls, Partitions, Floors, and Roofs

Structural Properties of One of the "Keystone Beam Steel Floor" Constructions Sponsored by the H. H. Robertson Co

Structural Properties of the Curren Fabrihome Corporation's "Fabrihome" Constructions for Walls and Partitions,

Structural Properties of "Steelox" Constructions for Walls, Partitions, Floors, and Roofs, Sponsored by Steel Buildings, Inc

Properties of Some Fiber Building Boards of Current Manufacture

Indentation and Recovery of Low-Cost Floor Coveringsby the Wheeling Corrugating Co

Structural Properties of a "Tilecrete" Floor Construction Sponsored by Tilecrete Floors, Inc -

Sound Insulation of Wall and Floor Constructions.

Structural Properties of "Pre-fab" Constructions for Walls, Partitions, and Floors Sponsored by Harnischfeger Corporation . . _ _

Preparation and Revision of Building Codes
Structural Properties of "Twachtman" Constructions for Walls and Floors Sponsored by Connecticut Pre-Cast Buildings Corporation

Structural Properties of a Concrete-Block Cavity-Wall Construction Sponsored by the National Concrete Masonry Association

Structural Properties of "Dun-Ti-Stone" Wall Construction Sponsored by the W. E. Dunn Manufacturing Co

Structural Properties of a Brick Cavity-Wall Construction Sponsored by the Brick Manufacturers Association of New York, Inc .

Structural Properties of a Reinforced-Brick Wall Construction and a Brick-Tile CavityWall Construction Sponsored by the Structural Clay Products Institute_........-

Structural Properties of Conventional Wood-Frame Constructions for Walls, Partitions,

Floors, and Roofs
Structural Properties of "Nelson Pre-Cast Concrete Foundation" Wall Construction

Sponsored by the Nelson Cement Stone Co., Inc
Structural Properties of "Bender Steel Home" Wall Construction Sponsored by the

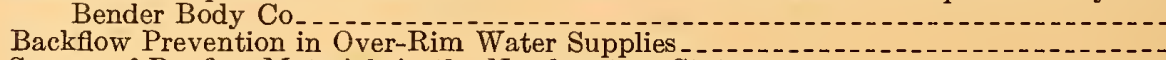

Survey of Roofing Materials in the Northeastern States Fir Plywood Association

Structural Properties of "Insulite" Wall and "Insulite" Partition Constructions Sponsored by The Insulite Co

Structural Properties of Two Brick-Concrete-Block Wall Constructions and a Concrete-Block Wall Construction Sponsored by the National Concrete Masonry Association Plastic Calking Materials Performance Test of Floor Coverings for Use in Low-Cost Housing: Part 1..... Stability of Sheathing Papers as Determined by Accelerated Aging. Part Structural Properties of Wood-Frame Wall, Partition, Floor, and Roof Constructions With "Red Stripe" Lath Sponsored by The Weston Paper and Manufacturing Co.-

*Out of print.

tSuperseded by BMS144.

tSuperseded by BMSix6. 


\section{Combustible Contents in Buildings}

S. H. Ingberg, John W. Dunham, and James P. Thompson

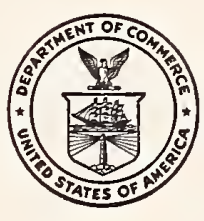

Building Materials and Structures Report 149

Issued July 25, 1957

For sale by the Superintendent of Documents, U. S. Government Printing Office, Washington 25, D. C. 


\section{Foreword}

The prevalent large building areas and heights require adequate fire resistance of structural supports and of subdividing constructions to restrict the spread of fire. The degree of fire resistance for the purpose is dependent on the severity of fires that can occur from burning of combustibles in contents and interior finish, floor, and trim. The present surveys were undertaken to obtain information on the amounts of combustibles associated with typical building occupancies. The data herein presented should be of assistance in constructing and equipping buildings to resist and restrict the fires that can occur within them.

A. M. Astin, Director.

\section{Contents}

1. Introduction

2. Basis and method of surveys $\ldots \ldots \ldots \ldots \ldots$

3. Tabulated results

3.1. Apartments and residences $\ldots \ldots \ldots 2$

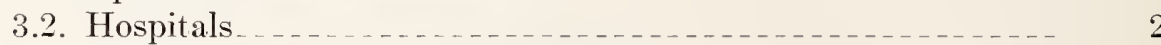

3.3. Schools $\ldots \ldots \ldots \ldots \ldots \ldots$

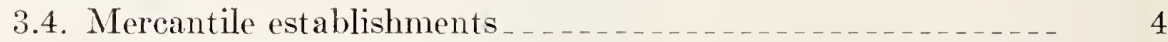

3.5. Manufacturing establishments

a. Furniture factories $\ldots \ldots \ldots$

b. Mattress factories $\ldots \ldots \ldots$

c. Clothing factories

3.6. Printing plants 10

3.7. Warehouses $\ldots \ldots \ldots \ldots \ldots$

3.8. Offices _...... 14

4. General notes and summary

4.1. Residential occupancies 15

4.2. Hospitals _... 15

4.3. Schools

4.4. Mercantile establishments _..._._.

4.5. Manufacturing establishments $\ldots \ldots \ldots \ldots \ldots \ldots$

4.6. Printing establishments

4.7. Warehouses $\ldots$

4.8. Office occupancies _........... 16

5. General objective and application 16

6. References 


\title{
Combustible Contents in Buildings
}

\author{
S. H. Ingberg, ${ }^{*}$ John W. Dunham, ${ }^{*}$ and James P. Thompson
}

Information is presented on the combustible contents, including the flooring and the interior finish and trim, found in buildings housing various classes of occupancy. The data givell are based on surveys of specific builuings in which the weight and distribution of combustible contents were obtained area by area and floor by floor. The results indicate the range in the amounts of combustibles associated with different occupancies and show that, except for the areas used for filing and storage, the combustible load is uniformly light for residential buildings, schools, hospitals, and office buildings. The combustible load varies considerably in mercantile occupancies and even more so in industrial and storage buildings. In conjunction with fire severity tests, data from these surveys can be applied in developing requirements for minimum fire resistance of buildings.

\section{Introduction}

In 1939, the Subcommittee on Fire Resistance Classifications of the Central Housing Committee on Research, Design, and Construction had surreys made of residential buildings, schools, hospital buildings, and warehouses to determine the amounts of combustible contents associated with those occupancies. A similar survey of office buildings had previousls been conducted by the $\mathrm{Na}$ tional Bureau of Standards. Information based upon these survers was published in 1942 [1].'

In 1947 , the Office of Technical Services in the Department of Commerce sponsored a number of investigations to assist in the solution of various business and industrial problems. The investigation of the weights of combustible contents in mercantile, industrial, and storage occupancies was undertaken at that time to complement and extend the information previously presented in BMSS92. The National Bureau of Standards assumed responsibility for the program and arranged to have the work done by the Public Buildings Administration (now the Public Buildings Service). Reports of the results of these surveys constitute the principal part of this publication.

Although not all of the occupancies defined by building codes were included in the surveys, those included were extensive enough to give a good indication of what can be expected. For example, the shoe or paint department in a department store could very well serve as the criterion for buildings containing either of these particular occupancies alone.

Evaluation of the resistance of buildings to the fires that occur in them requires not only a knowledge of the fire resistance of the construction, but an estimate of the potential severity of such fires. In tests conducted to obtain information on this subject [2], it was indicated that there is a fairly definite relation between the amount of combustible contents and the resulting fire severity expressed in hours as periods of exposure to the standard fire test [3].

To obtain an estimate of the probable fire severity in the various types of occupancies, the amounts of combustibles associated with these

\footnotetext{
*Guest worker. Formerly Chief, NBS Firc Protection Section (now

retired). ${ }^{*}$ Chief Structural Engineer, Public Buildings Service, General Services Administration.

I Figures in brackets indicate the literature references at the end of this report.
}

occupancies must be known or estimated. These combustibles include movable property such as furniture and goods, and combustible trim, finish, and flooring material.

This report presents a large volume of data on combustible loads found in a number of typical occupancies. The data are factual and should be helpful in designing buildings to resist fires involving prospective amounts of combustible contents.

\section{Basis and Method of Surveys}

Only the weights of combustible contents, finished flooring, interior finish, and trim are included in the weight totals. To combustible structural elements are included because they are a part of the building itself and not of the contents.

In general, the amounts of combustibles were obtained by weighing combustible furniture. equipment, goods, and other combustible contents in sufficient quantity to enable the total weight of such material within each area to be computed. The weight of any combustible flooring material, showcases, partitions, door and window trim, and built-in fixtures that could not be weighed was estimated from the thickness and area. All of the weights were converted to equivalent weights of combustibles having a calorific value in the range of wood and paper. A table giving the calorific value of rarious compounds and materials can be found in references $[2,5,6]$.

Where it was desired to segregate within closc limits the weights for individual rooms. such as in residences, schools, hospitals, and office buildings, one-half of the weight of common doors. door frames, and wood sash was allocatted to the respective rooms on each side of them. 'The' total weight of the combustible contents of metal lockers, filing cabinets, etc., wis incluelcel. Io weight was inclueded for possible eseaping illuminating gas.

Small enclosures, such as closets. were foumel to contain concentrations of combustible materials considerably higher than the arerage for the rest of the unit. Considering the small ares and the fact that wood eloset deors are genersilly of the type that will burn through in al short time, the contents and area of closits were areraged with those of the adjoining hall or room. 


\section{Tabulated Results}

The data presented in the tables show that the weights of combustible contents vary over a wide range among the different occupancies and, in some cases, for occupancies of the same type. These tables indicate the weight of combustibles per square foot of floor area associated with the occupancy surveyed and the area over which they were found. For some occupancies, summary tables give the percentage of the total area over which the weight of the combustibles within certain ranges were found and the largest single area within these ranges.

TABLE 1. Survey data for apartments and residences

(Data taken from BMS92)

\begin{tabular}{|c|c|c|c|c|c|c|c|c|}
\hline \multirow[b]{2}{*}{$\begin{array}{c}\text { Occupaney or } \\
\text { use }\end{array}$} & \multirow[b]{2}{*}{$\begin{array}{l}\text { Num- } \\
\text { ber of } \\
\text { rooms } \\
\text { sur- } \\
\text { veyed }\end{array}$} & \multirow[b]{2}{*}{$\begin{array}{c}\text { A ver- } \\
\text { age } \\
\text { ffoor } \\
\text { area }\end{array}$} & \multicolumn{3}{|c|}{$\begin{array}{l}\text { A verage combus- } \\
\text { tible contents }\end{array}$} & \multicolumn{3}{|c|}{ Total } \\
\hline & & & $\begin{array}{l}\text { Mov- } \\
\text { able } \\
\text { prop- } \\
\text { erty }\end{array}$ & Floor & $\begin{array}{l}\text { Ex- } \\
\text { posed } \\
\text { wood- } \\
\text { work } \\
\text { other } \\
\text { than } \\
\text { floor }\end{array}$ & $\begin{array}{l}\text { A ver- } \\
\text { age }\end{array}$ & $\begin{array}{l}\text { Maxi- } \\
\text { mum }\end{array}$ & $\begin{array}{l}\text { Mini- } \\
\text { mum }\end{array}$ \\
\hline & \multirow{3}{*}{$\begin{array}{r}1 \\
10\end{array}$} & \multirow{3}{*}{$\begin{array}{c}f t^{2} \\
783 \\
43\end{array}$} & \multirow{3}{*}{$\begin{array}{r}\imath b / f t^{2} \\
0.8 \\
1.0\end{array}$} & \multirow{3}{*}{$\begin{array}{r}l b / f t^{2} \\
0.0 \\
2.3\end{array}$} & \multirow{3}{*}{$\begin{array}{r}\tau b / f t^{2} \\
0.2 \\
3.7\end{array}$} & \multirow{3}{*}{$\begin{array}{r}l b / f t^{2} \\
1.0 \\
7.0\end{array}$} & $l b / f t^{2}$ & \multirow[t]{2}{*}{$l b / f t^{2}$} \\
\hline $\begin{array}{l}\text { Basement } \\
\text { Bathroom }\end{array}$ & & & & & & & 10.0 & \\
\hline $\begin{array}{l}\text { Bedroom } \\
\text { (closets }\end{array}$ & & & & & & & & \\
\hline ineluded) & \multirow[b]{2}{*}{$\begin{array}{r}18 \\
3 \\
12\end{array}$} & \multirow{2}{*}{$\begin{array}{l}132 \\
164.5 \\
40.5\end{array}$} & \multirow{2}{*}{$\begin{array}{l}5.0 \\
3.2 \\
1.0\end{array}$} & \multirow{2}{*}{$\begin{array}{l}2.8 \\
2.0 \\
3.0\end{array}$} & \multirow{2}{*}{$\begin{array}{l}2.6 \\
2.0 \\
6.5\end{array}$} & \multirow{2}{*}{$\begin{array}{r}10.4 \\
7.2 \\
10.5\end{array}$} & 13.2 & \multirow{2}{*}{$\begin{array}{l}6.8 \\
6.5 \\
7.5\end{array}$} \\
\hline $\begin{array}{l}\text { Dining room } \\
\text { Hallway }\end{array}$ & & & & & & & $\begin{array}{r}7.8 \\
13.7\end{array}$ & \\
\hline Kitehen & \multirow{2}{*}{$\begin{array}{r}11 \\
1 \\
12\end{array}$} & \multirow{2}{*}{$\begin{array}{l}119 \\
146 \\
203\end{array}$} & \multirow{2}{*}{$\begin{array}{r}1.2 \\
10.6 \\
3.9\end{array}$} & 2.5 & \multirow{2}{*}{$\begin{array}{l}3.1 \\
2.4 \\
1.8\end{array}$} & \multirow{2}{*}{$\begin{array}{r}6.8 \\
13.0 \\
8.1\end{array}$} & 10.7 & 2.9 \\
\hline $\begin{array}{l}\text { Library } \\
\text { Living room }\end{array}$ & & & & 2.4 & & & 10.4 & 5.7 \\
\hline $\begin{array}{l}\text { Storeroom } \\
\text { (apartment } \\
\text { house) }\end{array}$ & \multirow{2}{*}{$\begin{array}{l}6 \\
1\end{array}$} & \multirow{2}{*}{$\begin{array}{r}727 \\
22.5\end{array}$} & \multirow{2}{*}{$\begin{array}{l}6.4 \\
2.2\end{array}$} & 0.5 & \multirow{2}{*}{$\begin{array}{l}0.3 \\
4.4\end{array}$} & \multirow{2}{*}{$\begin{array}{l}7.2 \\
9.6\end{array}$} & 10.0 & \multirow[t]{2}{*}{2.4} \\
\hline Vestibule & & & & 3.0 & & & & \\
\hline $\begin{array}{l}\text { A verage for } \\
\text { complete } \\
\text { umits }\end{array}$ & 13 & 628.1 & 3.4 & 2.6 & 2.8 & 8.8 & 10.0 & 7.6 \\
\hline & nary & for $\mathrm{e}$ & ts in & esid & ntial bu & dings & & \\
\hline Closets: & & & & & & & & \\
\hline Linen & $\begin{array}{r}28 \\
9\end{array}$ & $\begin{array}{l}8.8 \\
4.8\end{array}$ & $\begin{array}{r}5.1 \\
11.7\end{array}$ & $\begin{array}{l}2.7 \\
3.0\end{array}$ & $\begin{array}{l}\begin{array}{l}11.6 \\
21.4\end{array} \\
\text {. }\end{array}$ & $\begin{array}{l}19.4 \\
3.1\end{array}$ & $\begin{array}{l}30.2 \\
49.3\end{array}$ & $\begin{array}{l}10.2 \\
26.2\end{array}$ \\
\hline Kitehen & 1 & 5.0 & 4.0 & 3.0 & 23. 2 & 39.2 & & \\
\hline
\end{tabular}

\subsection{Apartments and Residences}

The amounts of combustible contents found in apartments were so similar to those found in private residences that the two were grouped together. Table 1 gives the survey data for individual living and storage areas in a total of 13 apartments and residences, and the average combustible load for all the units taken as a whole. It is seen that the combustible load for a complete unit is relatively light, being not over $10 \mathrm{lb} / \mathrm{ft}^{2}$. Even in the storeroom areas this loading was not exceeded. To show the higher concentration of combustibles that exist in closets, table 1 also gives a summary for closets in residences, these concentrations being included with the adjoining rooms as given in the first part of the table.

\subsection{Hospitals}

St. Elizabeths Hospital, in Washington, D. C., was the only institutional-type occupancy included. Three buildings were surveyed, each housing the facilities necessary for a different type of treatment. Although St. Elizabeths is a psychiatric hospital, the results obtained may very well be typical of the general hospital occupancies covered, namely, neuropsychiatric continued treatment, tuberculosis infirmary, and medical and surgical.

Table 2 gives the results for the three buildings, and table 3 gives a summary of distribution for each building within given ranges of combustible contents. The average combustible loads for the various occupancies did not exceed $10 \mathrm{lb} / \mathrm{ft}^{2}$, except in the laundries, where it did not exceed 15 $\mathrm{lb} / \mathrm{ft}^{2}$.

\subsection{Schools}

The maximum combustible contents in school buildings were found in storerooms and libraries, whereas other portions of the buildings had a relatively light combustible load. The pupils'

TABLE 2. Survey data for hospital buildings, St. Elizabeths Hospital

(Data taken from BMS92)

\begin{tabular}{|c|c|c|c|c|c|c|c|c|c|}
\hline \multirow{4}{*}{ Oecupaney or use } & \multicolumn{7}{|c|}{ Medical and surgieal building } & \multicolumn{2}{|c|}{$\begin{array}{l}\text { A verage combustible } \\
\text { eontents }\end{array}$} \\
\hline & \multirow{3}{*}{$\begin{array}{l}\text { Number of } \\
\text { rooms or } \\
\text { units sur- } \\
\text { veyed }\end{array}$} & \multirow{3}{*}{$\begin{array}{l}\text { Total floor } \\
\text { area }\end{array}$} & \multicolumn{5}{|c|}{ Combustible contents } & \multirow{3}{*}{$\begin{array}{l}\text { Neuropsy- } \\
\text { chiatrie } \\
\text { continued- } \\
\text { treatment } \\
\text { hospital }\end{array}$} & \multirow{3}{*}{$\begin{array}{l}\text { Tubereu- } \\
\text { losis infir- } \\
\text { mary }\end{array}$} \\
\hline & & & \multirow{2}{*}{$\begin{array}{l}\text { Movable } \\
\text { property }\end{array}$} & \multirow{2}{*}{$\begin{array}{l}\text { Woodwork } \\
\text { and floor } \\
\text { covering }{ }^{1}\end{array}$} & \multicolumn{3}{|c|}{ Total } & & \\
\hline & & & & & A verage & Maximum & Minimum & & \\
\hline \multicolumn{10}{|c|}{ Administrative } \\
\hline $\begin{array}{l}\text { Administrative office } \\
\text { Doetors' office } \\
\text { Waiting rooms } \\
\text { Nurses' offices and rooms } \\
\text { Nurses' training school } \\
\text { Nurses' infirmary } \\
\text { Library and conference }\end{array}$ & $\begin{array}{r}6 \\
3 \\
3 \\
13 \\
12 \\
11 \\
11 \\
1\end{array}$ & $\begin{array}{r}f t^{2} \\
915 \\
945 \\
495 \\
1,728 \\
3,613 \\
1,599 \\
704\end{array}$ & $\begin{array}{r}l b / f t^{2} \\
6.3 \\
5.7 \\
1.4 \\
3.1 \\
2.2 \\
0.9 \\
5.2\end{array}$ & $\begin{array}{r}l b / f t^{2} \\
1.8 \\
2.9 \\
1.8 \\
1.9 \\
1.8 \\
2.2 \\
2.5\end{array}$ & $\begin{aligned} l b / f t^{2} \\
8.1 \\
8.6 \\
3.2 \\
5.0 \\
4.0 \\
3.0 \\
7.7\end{aligned}$ & $\begin{array}{r}l b / f t^{2} \\
13.4 \\
14.4 \\
4.1 \\
12.5 \\
14.5 \\
3.5 \\
-\end{array}$ & $\begin{array}{r}l b / f t^{2} \\
2.4 \\
5.1 \\
2.1 \\
3.1 \\
1.1 \\
2.5 \\
\end{array}$ & 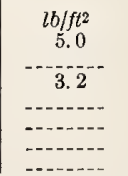 & \begin{tabular}{c}
$l b / f t^{2}$ \\
3.5 \\
2.9 \\
1.4 \\
3.7 \\
\hdashline-1. \\
\hdashline..--
\end{tabular} \\
\hline
\end{tabular}

See footnote at end of table. 
TABLE 2. Survey data for hospital buildings, St. Elizabeths Hospital-Continued

\begin{tabular}{|c|c|c|c|c|c|c|c|c|c|}
\hline \multirow{4}{*}{ Occupancy or use } & \multicolumn{7}{|c|}{ Medical and surgical building } & \multicolumn{2}{|c|}{$\begin{array}{c}\text { A verage combustible } \\
\text { contents }\end{array}$} \\
\hline & \multirow{3}{*}{$\begin{array}{l}\text { Number of } \\
\text { rooms or } \\
\text { units sur- } \\
\text { veyed }\end{array}$} & \multirow{3}{*}{$\begin{array}{l}\text { Total floor } \\
\text { area }\end{array}$} & \multicolumn{5}{|c|}{ Combustible contents } & \multirow{3}{*}{$\begin{array}{l}\text { Veuropsy- } \\
\text { chiatric } \\
\text { continuer- } \\
\text { treatmont } \\
\text { hospital }\end{array}$} & \multirow{3}{*}{$\begin{array}{l}\text { Tubercu- } \\
\text { losis infir- } \\
\text { mary }\end{array}$} \\
\hline & & & \multirow{2}{*}{$\begin{array}{l}\text { Movable } \\
\text { property }\end{array}$} & \multirow{2}{*}{$\begin{array}{l}\text { Wood work } \\
\text { and floor } \\
\text { covering } 1\end{array}$} & \multicolumn{3}{|c|}{ Total } & & \\
\hline & & & & & Average & Maximum & Minimum & & \\
\hline \multicolumn{10}{|c|}{ Service } \\
\hline $\begin{array}{l}\text { Corridors } \\
\text { Heating and mechanical services } \\
\text { Refrigeration } \\
\text { Kitchen } \\
\text { Laundry } \\
\text { Janitors' closets and supplies } \\
\text { Stores } \\
\text { Lockers and toilets }\end{array}$ & $\begin{array}{r}26 \\
4 \\
5 \\
7 \\
2 \\
10 \\
14 \\
8\end{array}$ & $\begin{array}{r}15,103 \\
1,009 \\
775 \\
3,259 \\
336 \\
989 \\
11,675 \\
1,766\end{array}$ & $\begin{array}{l}0.1 \\
1.9 \\
0.2 \\
4.4 \\
1.0 \\
1.7 \\
0.9\end{array}$ & $\begin{array}{l}2.6 \\
0.4 \\
1.9 \\
0.3 \\
.6 \\
1.4 \\
4.0 \\
0.5\end{array}$ & $\begin{array}{l}2.7 \\
0.5 \\
3.8 \\
0.5 \\
5.0 \\
2.4 \\
5.7 \\
1.4\end{array}$ & $\begin{array}{r}3.2 \\
1.7 \\
12.7 \\
4.7 \\
12.4 \\
7.8 \\
19.4 \\
2.9\end{array}$ & $\begin{array}{r}0.8 \\
.3 \\
.0 \\
.1 \\
3.8 \\
0.9 \\
1.5 \\
1.2\end{array}$ & $\begin{array}{c}2.4 \\
1.0 \\
13.1 \\
4.3 \\
2.1 \\
0.2\end{array}$ & $\begin{array}{c}1.2 \\
0.5 \\
1.7 \\
6.5 \\
1.4\end{array}$ \\
\hline \multicolumn{10}{|c|}{ Clinical } \\
\hline $\begin{array}{l}\text { Surgery } \\
\text { IIinor surgery and casts } \\
\text { Therapy and laboratories } \\
\text { Clinics. } \\
\text { Dormitories. } \\
\text { Rooms, single } \\
\text { Rooms, disturbed patients' } \\
\text { Day and waiting rooms } \\
\text { Porches, patients' } \\
\text { Sterilizers and clothing stores } \\
\text { Pharmacy, dispensary and stores } \\
\text { Diet kitchens and patients' dining } \\
\text { rooms } \\
\text { Laratories, etc.... }\end{array}$ & $\begin{array}{r}13 \\
2 \\
4 \\
33 \\
32 \\
28 \\
8 \\
3 \\
6 \\
4 \\
5 \\
9 \\
9\end{array}$ & $\begin{array}{r}4,307 \\
390 \\
978 \\
7,421 \\
11,223 \\
3,511 \\
1,016 \\
720 \\
3,566 \\
545 \\
1,172 \\
1,755 \\
2,304\end{array}$ & $\begin{array}{r}0.7 \\
2.1 \\
2.8 \\
2.0 \\
0.9 \\
.8 \\
.4 \\
.8 \\
.9 \\
1.4 \\
5.8 \\
1.2 \\
0.5\end{array}$ & $\begin{array}{l}1.1 \\
1.1 \\
1.6 \\
1.9 \\
1.6 \\
1.5 \\
2.5 \\
2.4 \\
0.4 \\
4.0 \\
1.9 \\
2.4 \\
1.4\end{array}$ & $\begin{array}{l}1.8 \\
3.2 \\
4.4 \\
3.9 \\
2.5 \\
2.3 \\
2.9 \\
3.2 \\
1.3 \\
5.4 \\
7.7 \\
3.6 \\
1.9\end{array}$ & $\begin{array}{r}10.6 \\
3.8 \\
7.3 \\
21.6 \\
3.6 \\
3.2 \\
3.2 \\
3.8 \\
2.3 \\
5.8 \\
11.5 \\
\\
5.2 \\
5.4\end{array}$ & $\begin{array}{l}0.2 \\
2.2 \\
2.5 \\
0.5 \\
1.7 \\
1.8 \\
2.2 \\
2.5 \\
0.9 \\
5.0 \\
6.8 \\
\\
2.7 \\
0.3\end{array}$ & $\begin{array}{c}2.5 \\
1.5 \\
2.1 \\
0.8 \\
0.5\end{array}$ & $\begin{array}{l}0.7 \\
1.8 \\
3.7 \\
3.7 \\
1.3 \\
4.0 \\
0.5\end{array}$ \\
\hline
\end{tabular}

${ }_{1}$ Combustible floor finish where present was 1/4-in.-thick linoleum, assumed to give equivalent in combustible material of $1 \mathrm{lb} / \mathrm{ft}^{2}$.

TABLE 3. Distribution of combustible contents, St. Elizabeths Hospital

\begin{tabular}{|c|c|c|c|}
\hline $\begin{array}{l}\text { Combustible contents for usable } \\
\text { floor area }\end{array}$ & $\begin{array}{l}\text { Medical } \\
\text { and } \\
\text { surgical } \\
\text { building }\end{array}$ & $\begin{array}{c}\text { Continued } \\
\text { treatment } \\
\text { building }\end{array}$ & $\begin{array}{c}\text { Tubercu- } \\
\text { losis } \\
\text { infirmary }\end{array}$ \\
\hline $\begin{array}{l}\quad l b / f t^{2} \\
5 \text { to } 4.9 \\
10 \text { to } 14.9 .9 \\
15 \text { to } 19.9 .9 \text { or more }\end{array}$ & $\begin{array}{l}\text { Percent } \\
82.1 \\
15.4 \\
1.6 \\
0.5 \\
.4\end{array}$ & $\begin{array}{l}\text { Percent } \\
91.0 \\
7.6 \\
0.7 \\
.7\end{array}$ & $\begin{array}{l}\text { Percent } \\
93.2 \\
0.3 \\
1.8 \\
4.4 \\
0.3\end{array}$ \\
\hline Usable floor area........ $\mathrm{ft}^{2}$ & 83,819 & 36,907 & $23,05+$ \\
\hline
\end{tabular}

wearing apparel and the contents of the desks were not included in the survey.

Table 4 gives a summary of the combustible contents for 4 high schools and 2 elementary schools in Washington, D. C., and vicinity. Except where heavy filing cases, library stacks, and storage of textbooks or materials were involved, the combustible load was found to be less than $15 \mathrm{lb} / \mathrm{ft}^{2}$.

From table 5 it is seen that less than 5 percent of the entire floor area of each building contained combustible loads in excess of $15 \mathrm{lb} / \mathrm{ft}^{2}$. Usually the rooms or areas with heavy combustible loads were in the basement, ground, or first floors. One
TABLE 4. Survey data for rooms in six school buildings in the Washington, D. C., aren

(Data taken from BMS92)

\begin{tabular}{|c|c|c|c|c|c|}
\hline \multirow[b]{2}{*}{ Oecupaney } & \multirow[b]{2}{*}{$\begin{array}{c}\text { A verage } \\
\text { floor } \\
\text { area }\end{array}$} & \multicolumn{4}{|c|}{ A verage combustible contents } \\
\hline & & $\begin{array}{l}\text { Mrov- } \\
\text { able } \\
\text { prop- } \\
\text { erty" }\end{array}$ & Floor & $\begin{array}{c}\text { Ex- } \\
\text { posed } \\
\text { wood- } \\
\text { work } \\
\text { other } \\
\text { than } \\
\text { floor }\end{array}$ & Total \\
\hline & $f t^{2}$ & $l b / f t^{2}$ & $l b / f t^{2}$ & $l b / f t=$ & $l b, f t=$ \\
\hline $\begin{array}{l}\text { Auditorium, gymnasium, } \\
\text { and lunchroom }\end{array}$ & 5,193 & $0 . \overline{7}$ & 4.2 & 1.5 & 6. 4 \\
\hline Typical classroom & 752 & 2.3 & 2.4 & 2.3 & 7. 0 \\
\hline $\begin{array}{l}\text { Labora tor ies: biolog y, } \\
\text { chemistry, physics, food, } \\
\text { and clothing. }\end{array}$ & 1,038 & 4.5 & 2.1 & 1.5 & s. 1 \\
\hline $\begin{array}{l}\text { Special classrooms: art, } \\
\text { bookkeeping, mechani- } \\
\text { cal drawing, typing, } \\
\text { physics lecture, wood- } \\
\text { working shop, library }\end{array}$ & 1335 & 6.2 & 23 & 19 & 10. $t$ \\
\hline $\begin{array}{c}\text { Offices: home economics, } \\
\text { publications, teachers... }\end{array}$ & 312 & S. 0 & 3.1 & 3.1 & 14. 2 \\
\hline $\begin{array}{l}\text { Library stackroom ... } \\
\text { Office and files }\end{array}$ & 264 & 23.4 & 2.1 & 5. $t$ & 33.9 \\
\hline Storerooms: & & 36.3 & & & \\
\hline Paint.... & 184 & t. 0 & 2.6 & 13. 1 & 10. - \\
\hline Janitor & 353 & 35.9 & 0.0 & 1.5 & 21 3 \\
\hline Lumber ..... & $\$ 80$ & 43.7 & 1.3 & $0 . \vdots$ & 45. -7 \\
\hline Paper....... & $\$ 25$ & 97.5 & 0.0 & $\therefore$ & 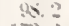 \\
\hline Textbook ........ & 590 & 172.3 & $\therefore$ & 6 & 1.3 .6 \\
\hline
\end{tabular}


TABLE 5. Data for six schools in the Washington, D. C., area showing the percentage of usable floor area having combustible contents within certain limits

\begin{tabular}{|c|c|c|c|c|c|c|}
\hline \multirow{3}{*}{$\begin{array}{c}\begin{array}{c}\text { Range of combustible } \\
\text { contents }\end{array} \\
l b / f t^{2}\end{array}$} & \multicolumn{2}{|c|}{$\begin{array}{l}\text { Elementary } \\
\text { scbools }\end{array}$} & \multicolumn{4}{|c|}{ Higb schoo!s } \\
\hline & $\begin{array}{l}\text { Per- } \\
\text { cent }\end{array}$ & $\begin{array}{l}\text { Per- } \\
\text { cent }\end{array}$ & $\begin{array}{l}\text { Per- } \\
\text { cent }\end{array}$ & $\begin{array}{l}\text { Per- } \\
\text { cent }\end{array}$ & $\begin{array}{l}\text { Per- } \\
\text { cent }\end{array}$ & Percent \\
\hline & 38.2 & 50.8 & 54.6 & 50.3 & 66.4 & 32.6 \\
\hline 5.0 to 9.9 & 58.5 & $4 \pi .1$ & 34.4 & 31. 0 & 25.4 & 64.1 \\
\hline 10.0 to 14.9 & 2.5 & 2.1 & 6.2 & 16.2 & 5.3 & 3.0 \\
\hline 15.0 to 24.9 & & -.-- & 1.0 & 0.3 & 0.2 & -..- \\
\hline $\begin{array}{l}25.0 \text { to } 34.9 \text { (general } \\
\text { storage) }\end{array}$ & $\cdots$ & --- & 2.3 & 1.0 & 2.0 & $\cdots$ \\
\hline $\begin{array}{l}35.0 \text { to } 49.9 \text { (general } \\
\text { storage) }\end{array}$ & \multirow{3}{*}{.8} & \multirow{2}{*}{ 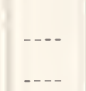 } & \multirow{2}{*}{$\begin{array}{l}1.2 \\
0.2\end{array}$} & 0.6 & 0.2 & \multirow{2}{*}{$\cdots$} \\
\hline $\begin{array}{l}50.0 \text { to } 74.5 \text { (wood or } \\
\text { paper storage) }\end{array}$ & & & & & & \\
\hline $\begin{array}{l}75.0 \text { to } 99.9 \text { (paper } \\
\text { storage) }\end{array}$ & & & & & .3 & \\
\hline 103.3 (paper storage) & -- & -. & 1 & ... & $\ldots$ & $-\ldots$ \\
\hline $\begin{array}{c}167.6 \text { (textbook stor- } \\
\text { agc) }\end{array}$ & & & & & & ..... \\
\hline $\begin{array}{l}255.7 \text { (textbook stor- } \\
\text { age) }\end{array}$ & & & & & & 3 \\
\hline 288 (textbook storage) & $-\cdots$ & $-\cdots$ & -... & -... & .2 & $\cdots$ \\
\hline Number of floors & 2 & 3 & 4 & 4 & 5 & 2 \\
\hline Usable floor area $\mathrm{ft}^{2}$ & 31,30 & 40,05 & 130,9 & $125, ?$ & 254,619 & ${ }^{c} 24,177$ \\
\hline
\end{tabular}

s Exclusive of basement, wbich contains boiler room only.

b Exclusive of temporary wooden corridor.

Excludes attic and basement, which latter contains boiler room only.

small textbook-storage room and a large library stackroom were found on the second floor in these buildings. Janitors' and gencral storerooms with average combustible loads near $25 \mathrm{lb} / \mathrm{ft}^{2}$ were found on upper as well as lower floors in one or more of these buildings. Their individual and aggregate areas, however, were relatively small.

\subsection{Mercantile Establishments}

The department store is unique in that there arc contained within its various departments practically all of the characteristics common to single mercantile occupancies handling similar merchandise. As a result, these data have a wide scope of usefulness.

The New York, N. Y., department store selected was of such size that a complete survey was not feasible; therefore, the survey was limited to the selling areas and small storage areas frequented by the clerks, but did not include workshops, packing rooms, tube rooms, offices, etc., associated with the selling areas. The tentli through the twentieth floors, which were used for storage and offices, were also omitted. The combustible load per square foot for a whole department was determined by weighing the combustible contents in a representative area of the department.

The second-floor plan of a department store in Washington, D. C., figure $1,^{2}$ shows a typical department arrangement and the combustible loads that were found to exist at the time of the survey. Although stores of this type are continually making minor changes in arrangement, the floor plan shown indicates the combustible-load differential of the various departments, the higher accumu- lation of combustibles in storage areas as compared to sales areas, and the ready manner in which storage areas can be established anywhere throughout the area. The load is assumed to be uniformly distributed over each area, including the area of aisle spaces.

Tables $6 \mathrm{a}$ and $6 \mathrm{~b}$ give a summary of combustible loads by floors. For 4 floors of the New York City store the average was below $10 \mathrm{lb} / \mathrm{ft}^{2}$, and for the 6 others the lighest average for any 1 floor was $13.4 \mathrm{lb} / \mathrm{ft}^{2}$. For the Washington, D. C., store the average was not over $10 \mathrm{lb} / \mathrm{ft}^{2}$ for 6 floors, and the highest individual average for the 2 other floors was $12.6 \mathrm{lb} / \mathrm{ft}^{2}$.

TABle 6a. Survey data for a department store in New York City

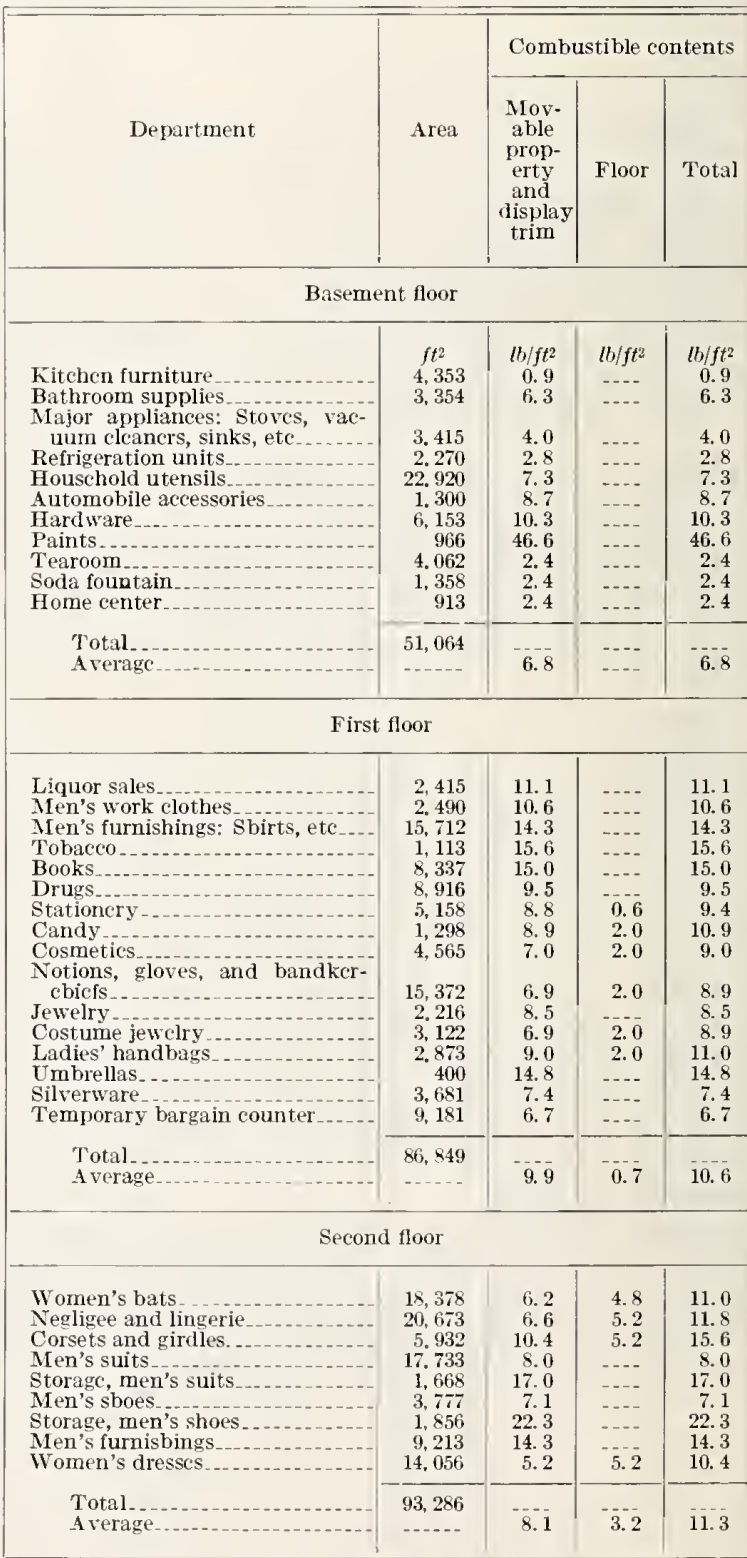

${ }^{2}$ Figures are given at the end of this report. 
TABLE 6a. Survey data for a department slore in New York Cily-Continued

\begin{tabular}{|c|c|c|c|c|}
\hline \multirow[b]{2}{*}{ Department } & \multirow[b]{2}{*}{ Area } & \multicolumn{3}{|c|}{ Combustible contents } \\
\hline & & $\begin{array}{l}\text { Mov- } \\
\text { able } \\
\text { prop- } \\
\text { erty } \\
\text { and } \\
\text { display } \\
\text { trim }\end{array}$ & Floor & Total \\
\hline \multicolumn{5}{|c|}{ Third floor } \\
\hline $\begin{array}{l}\text { Fur storage, cleaning, and repair- } \\
\text { ing } \\
\text { Women's dresses } \\
\text { Budget furs } \\
\text { Women's suits and coats } \\
\text { Better furs. } \\
\text { Women's beach wear. }\end{array}$ & \begin{tabular}{r}
\multicolumn{1}{c}{$f t^{2}$} \\
6,415 \\
22,600 \\
4,917 \\
49,382 \\
5,451 \\
10,811
\end{tabular} & $\begin{array}{l}l b / f t^{2} \\
7.8 \\
5.2 \\
2.6 \\
5.6 \\
6.2 \\
9.0\end{array}$ & \begin{tabular}{l}
$\mathrm{lb} / \mathrm{ft}^{2}$ \\
- \\
\hdashline 5.2 \\
5.2 \\
5.2
\end{tabular} & $\begin{array}{r}t t / f t^{2} \\
7.8 \\
5.2 \\
2.6 \\
10.8 \\
11.4 \\
14.2\end{array}$ \\
\hline $\begin{array}{l}\text { Total_- } \\
\text { Arerage }\end{array}$ & 99,576 & 5.9 & 3.4 & 9.3 \\
\hline \multicolumn{5}{|c|}{ Fourth floor } \\
\hline $\begin{array}{l}\text { Children's shoes } \\
\text { Storage, children's shoes. } \\
\text { Children's hose } \\
\text { Girls' clothing } \\
\text { Children's clothing } \\
\text { Girls' dresses } \\
\text { Infants' furnishings } \\
\text { Temporary bargain counter }\end{array}$ & $\begin{array}{r}9.722 \\
2,968 \\
820 \\
12,083 \\
6,530 \\
9,716 \\
12,127 \\
766\end{array}$ & $\begin{aligned} 5.1 \\
20.5 \\
11.1 \\
9.3 \\
11.3 \\
7.1 \\
5.6 \\
6.7\end{aligned}$ & $\begin{array}{l}5.2 \\
5.2 \\
5.2 \\
5.2 \\
5.2 \\
5.2 \\
5.2 \\
5.2\end{array}$ & $\begin{array}{l}10.3 \\
25.7 \\
16.3 \\
14.5 \\
16.5 \\
12.3 \\
10.8 \\
11.9\end{array}$ \\
\hline $\begin{array}{l}\text { Total.-.----.-. } \\
\text { Arerage }\end{array}$ & $54, i 32$ & 8.2 & 5.2 & 13.4 \\
\hline
\end{tabular}

Fifth floor

\begin{tabular}{|c|c|c|c|c|}
\hline Boys' camp equipment. & 4,080 & 9.3 & & 9.3 \\
\hline Boys' clothing & 14,323 & 6.8 & & 6.8 \\
\hline Toys .................. & 12,089 & 3.2 & & 3.2 \\
\hline Playground equipment.. & 5,054 & 2.4 & 5.2 & 7. 6 \\
\hline Sporting goods & 10,707 & 5.2 & 5.2 & 10.4 \\
\hline Radios and phonographs.. & 4,299 & 4.7 & 5.2 & 9.9 \\
\hline Crosley automobiles.... & 720 & 2.4 & 5.2 & 7.6 \\
\hline Airplanes. & 500 & 2.4 & 5.2 & 7.6 \\
\hline Pianos.................. & 3,280 & 6.1 & 5.2 & 11.3 \\
\hline Commercial stationery ....... & 1.967 & 8.3 & 5.2 & 13.5 \\
\hline Cameras, etc & 3. 194 & 9.1 & 5.2 & 14.3 \\
\hline Art supplies & 2,203 & 13. 3 & 5.2 & 18.5 \\
\hline Phonograph records & 6,400 & 29.2 & 5.2 & 34.4 \\
\hline Toys & 6,904 & 3.2 & 5.2 & 8.4 \\
\hline Tots & 75,720 & & & \\
\hline Average & -..... & 7.5 & 3.1 & 10.6 \\
\hline
\end{tabular}

Sixth floor

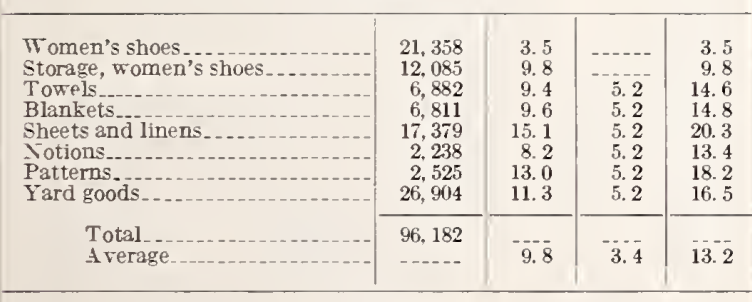

Seventh floor

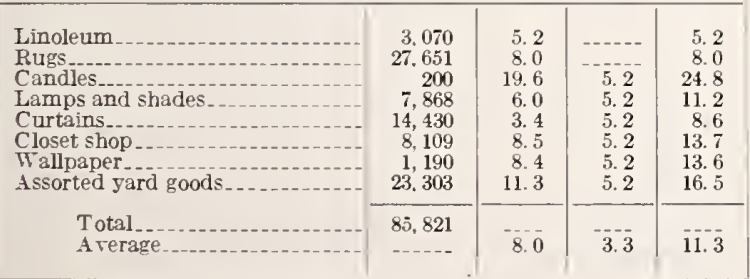

TABLE 6a. Survey data for a deparment slore in Nen York City-Continued

\begin{tabular}{|c|c|c|c|c|}
\hline \multirow[b]{2}{*}{ Department } & \multirow[b]{2}{*}{ Area } & \multicolumn{3}{|c|}{ Combustible contents } \\
\hline & & $\begin{array}{l}\text { Mov- } \\
\text { able } \\
\text { prop- } \\
\text { erty } \\
\text { and } \\
\text { display } \\
\text { trim }\end{array}$ & Floor & Total \\
\hline \multicolumn{5}{|c|}{ Eighth floor } \\
\hline $\begin{array}{l}\text { Food } \\
\text { Glassware } \\
\text { Chinaware } \\
\text { Pictures and frames. } \\
\text { Luggage }\end{array}$ & $\begin{array}{r}f t^{2} \\
10,190 \\
9,438 \\
19,241 \\
7,253 \\
8,149\end{array}$ & $\begin{array}{l}\text { tb/ft2 } \\
7.0 \\
5.2 \\
8.3 \\
4.6 \\
5.2\end{array}$ & \begin{tabular}{c}
$\left(b_{1} / f t^{2}\right.$ \\
5.2 \\
\hdashline-1 \\
\hdashline-1
\end{tabular} & $\begin{array}{l}l b / f t^{2} \\
12.2 \\
5.2 \\
8.3 \\
4.6 \\
5.2\end{array}$ \\
\hline Total & 54,274 & $6 . \overline{5}$ & $1 . \overline{0}$ & 7.5 \\
\hline \multicolumn{5}{|c|}{ Ninth floor } \\
\hline $\begin{array}{l}\text { Bedroom furniture } \\
\text { Dining room and oceasional fur- } \\
\text { niture } \\
\text { Modern furniture. }\end{array}$ & $\begin{array}{l}24,929 \\
55,847 \\
12,513\end{array}$ & $\begin{array}{l}4.0 \\
3.4 \\
9.3\end{array}$ & $\begin{array}{l}5.2 \\
5.2 \\
5.2\end{array}$ & $\begin{array}{r}3.2 \\
8.6 \\
14.5\end{array}$ \\
\hline Total & 93,289 & 4. 4 & 5.2 & 9.6 \\
\hline
\end{tabular}

TABLE 6b. Survey data for a department store in Washington, $D$. $C$.

\begin{tabular}{|c|c|c|c|c|}
\hline \multirow[b]{2}{*}{ Department } & \multirow[b]{2}{*}{ Area } & \multicolumn{3}{|c|}{ Combustible contents } \\
\hline & & $\begin{array}{l}\text { Mov- } \\
\text { able } \\
\text { prop- } \\
\text { erty } \\
\text { and } \\
\text { display } \\
\text { trim }\end{array}$ & Floor & Total \\
\hline
\end{tabular}

First floor

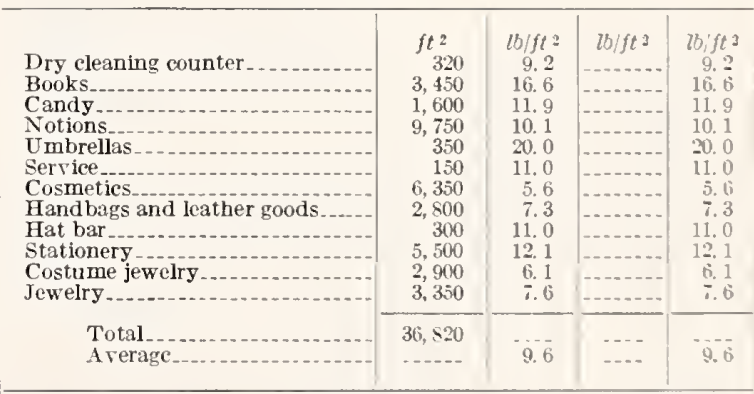

Second floor

\begin{tabular}{|c|c|c|c|c|}
\hline Dry goods, patterns, and art goods & S. 752 & 9.9 & & 9.9 \\
\hline Ladies' shoe stockroom............ & 2,000 & 32. & & 325 \\
\hline Children's shoe stockroom ........ & 955 & 21 & - .. & 2.1 \\
\hline Shoe sale space & 3. 94 & $3, i$ & ..... & 31 \\
\hline $\begin{array}{l}\text { Storage, men's hats, shoes, to- } \\
\text { baeco, etc. }\end{array}$ & & 31.7 & $\ldots$ & \\
\hline Men's elothing & 10,$22 ;$ & 12.0 & ... & 120 \\
\hline Tot: & 32, , lis & & & \\
\hline Alu & & 126 & & \\
\hline
\end{tabular}


TABLE 6b. Survey data for a department store in Washington, D.C.-Continued

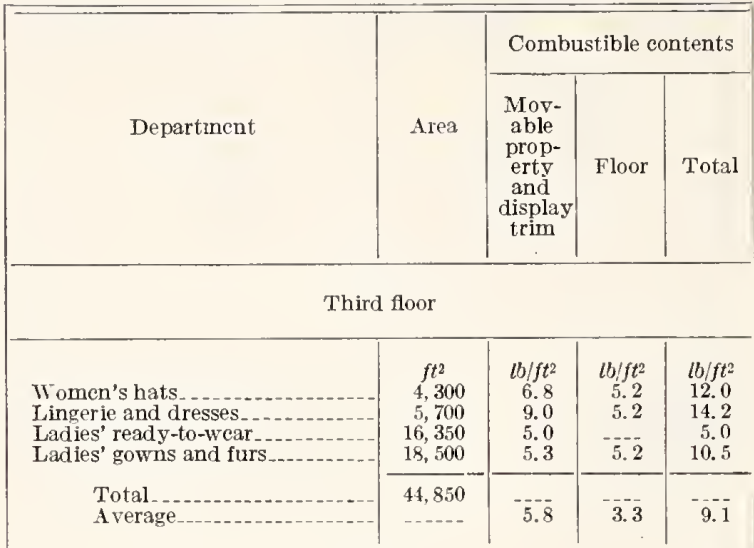

Fourth floor

\begin{tabular}{|c|c|c|c|c|}
\hline Boy's clot & 3,830 & 13.6 & 5.2 & 18.8 \\
\hline Infant and juvenile clothing... & 11,934 & 8.05 & $-\ldots$ & 8.05 \\
\hline Camera and radio & 3,958 & 5.9 & & 5.9 \\
\hline Music & 2.870 & 24.3 & 4.0 & 28.3 \\
\hline Junior misses. & 14,022 & 4.9 & -..- & 4.9 \\
\hline $\begin{array}{l}\text { Total } \\
\text { A verage }\end{array}$ & 36,614 & 8.5 & 0.8 & 9.3 \\
\hline
\end{tabular}

Fifth floor

\begin{tabular}{|c|c|c|c|c|}
\hline Gift shop & 2,800 & 9.7 & & 9.7 \\
\hline China and glass. & 11,400 & 6.2 & $\ldots-$ & 6.2 \\
\hline Linen and towels. & 5,500 & 9.5 & & \\
\hline Bedroom furniture & 15,800 & 5.6 & 5.2 & 10.8 \\
\hline Bedding - & 4,350 & 10.1 & & 10.1 \\
\hline Carpenter and paint shop.- & 2,600 & 20.8 & 5.2 & 26.0 \\
\hline China and glass storage & 440 & 11.4 & & 11.4 \\
\hline General wrapping & 1,550 & 9.7 & 3.9 & 13.6 \\
\hline Total. . & 44,440 & & & \\
\hline & & 8.0 & 2.3 & 10.3 \\
\hline
\end{tabular}

Sixth floor

\begin{tabular}{|c|c|c|c|c|}
\hline Furniture display room & 8,145 & 5.8 & 1.4 & 7.2 \\
\hline Employees' cafeteria_- & 1,496 & 4.8 & 5.2 & 10.0 \\
\hline Rug department. & 10.925 & 10.2 & 5.2 & 15.4 \\
\hline Foyer & 780 & 3.1 & 5.2 & 8.3 \\
\hline Storage and shipping room for & & & & \\
\hline rug and linoleum & 822 & 22.8 & 5.2 & 28.0 \\
\hline $\begin{array}{l}\text { Furniture } \\
\text { Miscellaneous furniture and of- }\end{array}$ & 14,200 & 4.0 & 1.7 & 5.7 \\
\hline $\begin{array}{l}\text { Miscellaneous furniture and of- } \\
\text { fice }\end{array}$ & 2,468 & 7.7 & & 7.7 \\
\hline Interior decorating & 1,420 & 16.3 & 5.2 & 21.5 \\
\hline $\begin{array}{l}\text { Total } \\
\text { A verage }\end{array}$ & 40,256 & 7.0 & 3.0 & 10.0 \\
\hline
\end{tabular}

\section{Seventh fioor}

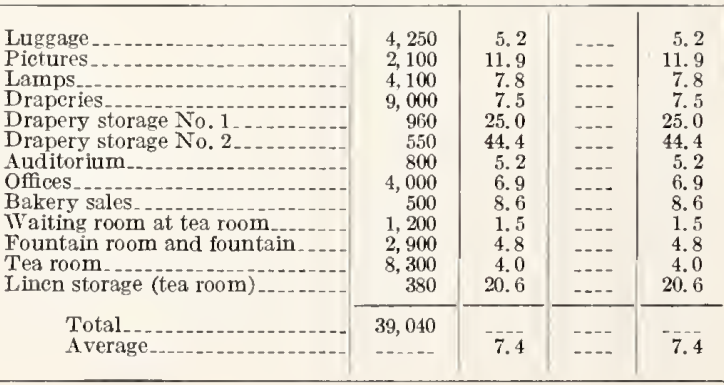

TABLE 6b. Survey data for a department store in Washington, D. C.-Continued

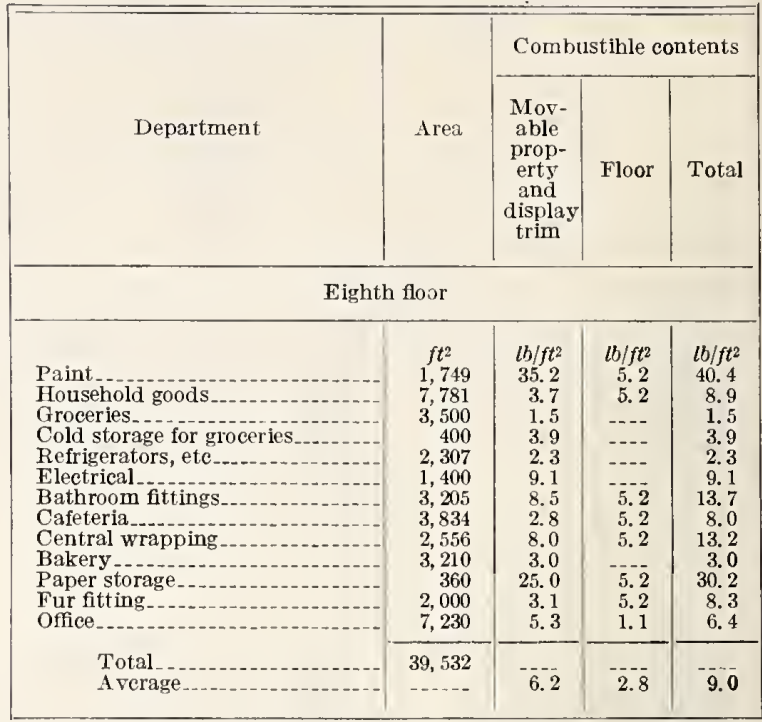

TABLE 6c. Summary of combustible loads in department stores by occupancies

(Comhustible weight of flooring and covering not included)

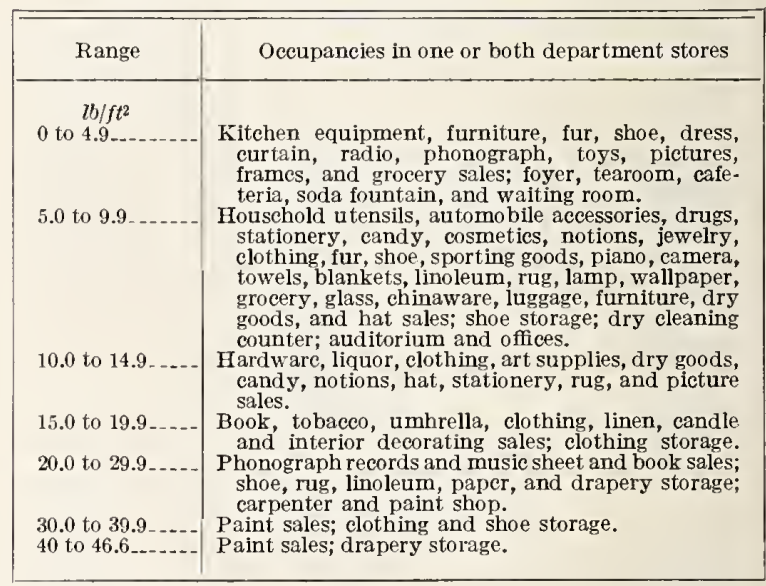

TABLE 6d. Percentage of department-store floor area having combustible contents within certain limits

\begin{tabular}{|c|c|c|c|c|}
\hline \multirow{2}{*}{$\begin{array}{l}\text { Range of comhustihle } \\
\text { contents }\end{array}$} & \multicolumn{2}{|c|}{$\begin{array}{c}\text { Washington } \\
\text { (Total floor area, } \\
314,239 \mathrm{ft}^{2} \text { ) }\end{array}$} & \multicolumn{2}{|c|}{$\begin{array}{c}\text { New York } \\
\text { (Total floor area, } \\
790,793 \mathrm{ft}^{2} \text { ) }\end{array}$} \\
\hline & $\begin{array}{l}\text { Part of } \\
\text { total } \\
\text { floor } \\
\text { area }\end{array}$ & $\begin{array}{c}\text { Largest } \\
\text { single } \\
\text { area } \\
\text { within } \\
\text { range }\end{array}$ & $\begin{array}{l}\text { Part of } \\
\text { total } \\
\text { floor } \\
\text { area }\end{array}$ & $\begin{array}{c}\text { Largest } \\
\text { single } \\
\text { area } \\
\text { within } \\
\text { range }\end{array}$ \\
\hline $\begin{array}{l}0.0 \text { to } 4.9 / f t^{2} \\
5.0 \text { to } 9.9 \\
10.0 \text { to } 14.9 \\
15.0 \text { to } 19.9 \\
20.0 \text { to } 29.9 \\
30.0 \text { to } 39.9 \\
40 \text { and } 0 \text { orer }\end{array}$ & $\begin{array}{l}\text { Percent } \\
12.6 \\
46.7 \\
29.9 \\
5.8 \\
3.4 \\
0.9 \\
.7\end{array}$ & $\begin{array}{r}f t^{2} \\
14,022 \\
16,350 \\
18,500 \\
10,925 \\
2,870 \\
2,000 \\
1,749\end{array}$ & $\begin{array}{c}\text { Percent } \\
7.8 \\
43.1 \\
35.3 \\
10.0 \\
2.8 \\
0.8 \\
.2\end{array}$ & $\begin{array}{r}f t^{2} \\
21,358 \\
55,875 \\
49,382 \\
26,904 \\
17,379 \\
6,400 \\
966\end{array}$ \\
\hline
\end{tabular}


Table $6 c$ gives a summary of the combustible loads contributed by movable property and display trim in department stores as related to the type of goods sold or stored, based on tables 6 a and $6 \mathrm{~b}$. The majority of the sales areas had combustible loads of $10 \mathrm{lb} / \mathrm{ft}^{2}$ or less, some had loads between 10 and $20 \mathrm{lb} / \mathrm{ft}^{2}$, and a few, including sales areas for books and for paints, had higher loads. Storage of clothing, rugs, shoes, paper, and drapery material gave combustible loads in the range from 15 to $46.6 \mathrm{lb} / \mathrm{ft}^{2}$.

The percentage of department-store areas having combustible loads between given limits is shown in table $6 \mathrm{~d}$. It is seen that from 50 to 60 percent of the floor area had combustible loads not over $10 \mathrm{lb} / \mathrm{ft}^{2}$, from 30 to 35 percent had between 10 and $15 \mathrm{lb} / \mathrm{ft}^{2}, 10$ percent had between 15 and $20 \mathrm{lb} / \mathrm{ft}^{2}$, and no more than 5 percent of the area had more than $20 \mathrm{lb} / \mathrm{ft}^{2}$.

\subsection{Manufacturing Establishments}

The surveys of manufacturing occupancies included 2 furniture factories, 2 mattress factories, a women's clothing factory, and a men's clothing factory. Where more than one area is used for the same purpose, separate entries are made in the tables for each area.

\section{a. Furniture Factories}

All of the buildings or portions of buildings used in the production, shipping, storage, and display of furniture were surveyed. Outside lumber storage and service buildings were not included.

The Gettysburg, Pa., factory surveyed had 20 buildings, of 1 story, 1 story and basement, or 2 stories, nearly all contiguous with structural separations. The floor and roof constructions of all buildings were of wood, but all except buildings 11 and 12 had masonry exterior and interior walls. Figure 2 shows the building layout. In determining the combustible content of the first floor of the shipping and storage building, it was assumed that the contents of a car of furniture loaded just prior to the survey were in the shipping-room area.

The Grand Rapids, Mich., factory was housed in 18 buildings, all but 3 of which were contiguous. Most of them had 3 or 4 stories, with or without basements. They were largely of heavy-timber construction. A 3-story building used in part for exhibition purposes was of reinforced-concrete construction.

Tables $7 \mathrm{a}$ and $7 \mathrm{~b}$ give the survey data for the two furniture factories, and table $7 \mathrm{c}$ gives the percentage of the total area with combustibles within a given range and the largest single area over which combustibles within these ranges were found.

In the lower range of combustible contents, there was a marked difference found for the two plants. For the Gettysburg plant, only $1 \frac{1}{2}$ percent of the floor area had combustibles in an
TABLE 7a. Survey data for furniture foctory in Gettysturg, Po.

See figure 2 for building layout.

\begin{tabular}{|c|c|c|c|c|c|c|}
\hline \multirow{2}{*}{$\begin{array}{l}\text { Build- } \\
\text { ing }\end{array}$} & \multirow{2}{*}{ Area } & \multirow{2}{*}{$\begin{array}{l}\text { Occupancy } \\
\text { or use }\end{array}$} & \multirow{2}{*}{$\begin{array}{l}\text { Flow } \\
\text { area }\end{array}$} & \multicolumn{3}{|c|}{$\begin{array}{l}\text { Combustible } \\
\text { comtents }\end{array}$} \\
\hline & & & & $\begin{array}{l}\text { Other } \\
\text { than } \\
\text { foor }\end{array}$ & Flror & Total \\
\hline $\begin{array}{l}3 \ldots \\
4 \ldots \\
5\end{array}$ & $\begin{array}{l}a \\
b \\
c \\
d \\
e \\
f\end{array}$ & $\begin{array}{l}\text { Boiler house } \\
\text { Millwork } \\
\text { do } \\
\text { Glue room } \\
\text { Office } \\
\text { Pattern room } \\
\text { Staining } \\
\text { Spraying } \\
\text { Finishing } \\
\text { Paint sbop. } \\
\end{array}$ & $\begin{array}{r}f t^{2} \\
(i) \\
5,450 \\
3,100 \\
760 \\
1.030 \\
130 \\
130 \\
3,900 \\
10,200 \\
5,920 \\
216\end{array}$ & $\begin{array}{r}c b / f t^{3} \\
(i) \\
15.8 \\
12.0 \\
22.1 \\
8.0 \\
4.5 \\
9.8 \\
6.3 \\
7.9 \\
7.1 \\
99.3\end{array}$ & $\begin{array}{c}v_{1} / t^{2} \\
(i) \\
5.2 \\
5.2 \\
5.2 \\
5.2 \\
5.2 \\
5.2 \\
5.2 \\
5.2 \\
5.2 \\
5.2\end{array}$ & $\begin{array}{r}v y / f t^{2} \\
(i) \\
21.0 \\
17.2 \\
27.3 \\
13.2 \\
9.7 \\
15.0 \\
11.5 \\
13.1 \\
12.3 \\
104.5\end{array}$ \\
\hline $\begin{array}{l}6 . \\
7 .\end{array}$ & $\begin{array}{l}\text { Basement } \\
\text { First floor } \\
\text { a } \\
\text { Basement } \\
\text { First floor. }\end{array}$ & $\begin{array}{l}\text { Dry kilns. } \\
\text { Millwork } \\
\text { Storage a } \\
\text { Cabinet work } \\
\text { and storage b.- } \\
\text { Cabinet manu- }\end{array}$ & $\begin{array}{r}5,660 \\
5,600 \\
5,600 \\
598 \\
7,450 \\
7,100\end{array}$ & $\begin{array}{l}68.9 \\
15.6 \\
13.3 \\
95.9 \\
48.7 \\
13.2\end{array}$ & $\begin{array}{l}-. \\
5.2 \\
5.2 \\
-. \\
5.2\end{array}$ & $\begin{array}{r}68.9 \\
15.6 \\
15.5 \\
101.1 \\
48.7 \\
18.4\end{array}$ \\
\hline $\begin{array}{l}9 \ldots . \\
10 \ldots\end{array}$ & $\begin{array}{l}\text { Basement } \\
\text { First floor }\end{array}$ & $\begin{array}{l}\text { facture. } \\
\text { do } \\
\text { Storagec } \\
\text { Spraying }\end{array}$ & $\begin{array}{l}4,650 \\
2,800 \\
2,750\end{array}$ & $\begin{array}{r}15.9 \\
62.9 \\
6.5\end{array}$ & $\begin{array}{l}5.2 \\
5.2\end{array}$ & $\begin{array}{l}21.1 \\
62.9 \\
11.7\end{array}$ \\
\hline $\begin{array}{l}11 \ldots \ldots \\
12 \ldots \ldots \\
13 \ldots \\
14 \ldots \\
15 \ldots \\
16 \ldots\end{array}$ & 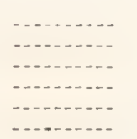 & $\begin{array}{l}\text { Storage d } \\
\quad \text { do } \\
\text { Varnish vault } \\
\text { Lumber shed } \\
\text { Pumap house } \\
\text { Rubbing and }\end{array}$ & $\begin{array}{c}2,750 \\
2,360 \\
600 \\
(i) \\
6,200\end{array}$ & $\begin{array}{c}30.8 \\
83.0 \\
16.5 \\
\text { (i) } \\
5.1\end{array}$ & $\begin{array}{l}5.2 \\
- \\
\text { (i) } \\
5.2\end{array}$ & $\begin{array}{r}36.0 \\
83.0 \\
16.5 \\
\text { (i) } \\
10.3\end{array}$ \\
\hline $\begin{array}{l}17 . \\
18 .\end{array}$ & $\begin{array}{l}\text { First floor } \\
\text { Second }\end{array}$ & $\begin{array}{c}\text { polishing. } \\
\text { Storage }{ }^{-} \\
\text {do } \\
-\end{array}$ & $\begin{array}{l}5,850 \\
7,400 \\
7,400\end{array}$ & \begin{tabular}{l|}
12.0 \\
15.6 \\
12.0
\end{tabular} & $\begin{array}{l}5.2 \\
5.2 \\
5.2\end{array}$ & $\begin{array}{l}17.2 \\
20.8 \\
17.2\end{array}$ \\
\hline $\begin{array}{l}19 \ldots \\
20 \ldots\end{array}$ & $\begin{array}{l}\text { First floor -- } \\
\text { Second } \\
\text { floor. }\end{array}$ & $\begin{array}{l}\text { Finishing } \\
\text { Shipping and } \\
\text { storage } \text {. } \\
\text { Storage } \\
\text {. }\end{array}$ & $\begin{array}{r}1,750 \\
9.675 \\
10,625\end{array}$ & \begin{tabular}{r|r|}
4.7 & \\
11.4 & \\
13.6 &
\end{tabular} & $\begin{array}{l}5.2 \\
5.2 \\
5.2\end{array}$ & $\begin{array}{r}9.9 \\
16.6 \\
15.8\end{array}$ \\
\hline & 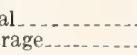 & & 127.654 & 19.3 & 4.6 & 23. ? \\
\hline
\end{tabular}

a Lumber being transferred from dry kilns.

b Plywood panels loaded on trucks.

e Plywood (3-ply).

d Veneer and packing material.

e Furniture.

f Furniture and packing material.

g Furniture (some crated ready to ship).
h Furniture (chairs).

i Not surveyed.

amount less than $10 \mathrm{lb} / \mathrm{ft}^{2}$; whereas for Grand Rapids, over one-half of the area was thus relatively lightly loaded. 'This was due in part to a somewhat lighter wood flooring in the Cround Rapids plant.

A generally lighter combustible loading for the latter plant is also indicated by a relatively small percentage of the floor area having combustible loads in the higher ranges. Eight pereent of the area for the Grand Rapids plant and about 17 percent of that at Gettrsburg had combustibles of $30 \mathrm{lb} / \mathrm{ft}^{2}$ or over. These arens were confined to spaces used for storage, air and kiln drying. and paint and lacquer shops and raults.

\section{b. Mattress Factories}

Two establishments manufacturing matresses were survered, one in Atlanta, Ga., and the ofher 
TABLE 7b. Survey data for furniture factory in Grand Rapids, Mich.

\begin{tabular}{|c|c|c|c|c|c|c|c|}
\hline \multirow{2}{*}{ Occupancy ol use } & \multirow{2}{*}{$\begin{array}{c}\text { Num- } \\
\text { her of } \\
\text { units } \\
\text { sur- } \\
\text { veyed }\end{array}$} & \multirow{2}{*}{$\begin{array}{l}\text { Total } \\
\text { floor } \\
\text { area }\end{array}$} & \multicolumn{3}{|c|}{$\begin{array}{l}\text { Average combus- } \\
\text { tible contents }\end{array}$} & \multirow{2}{*}{$\begin{array}{l}\text { aMax- } \\
\text { imum }\end{array}$} & \multirow{2}{*}{$\begin{array}{l}\text { Mini- } \\
\text { mum }\end{array}$} \\
\hline & & & $\begin{array}{l}\text { Other } \\
\text { than } \\
\text { floor }\end{array}$ & Floor & Total & & \\
\hline & & $f t^{2}$ & $l b / f t^{2}$ & $l b / f t^{2}$ & $l b / f t^{2}$ & $l b / f t^{2}$ & $l b / f t^{2}$ \\
\hline Photo studio... & 1 & 4,970 & 1.8 & 0.0 & 1.8 & - & -.. \\
\hline Exhibition & 1 & 9,940 & 3.4 & .0 & 3.4 & - & $\ldots$ \\
\hline Trucking area.. & 1 & 2,670 & 0.0 & 4.0 & 4.0 & -. & $\ldots$ \\
\hline Smoking room. & 1 & 720 & 5. 7 & 0.0 & 5. 7 & - & $\ldots$ \\
\hline Kitchen & 1 & 750 & 7.1 & .0 & 7.1 & - - &.- \\
\hline $\begin{array}{l}\text { Cabinct and assem- } \\
\text { bly work }\end{array}$ & 7 & 71,365 & 3.4 & 4.0 & 7.4 & 14.2 & 6.4 \\
\hline Shipment makeup.- & 4 & 34,900 & 3.9 & 4.0 & 7.9 & 10.7 & 7.0 \\
\hline Finishing & 8 & 80,320 & 4. 7 & 4.0 & 8.7 & 13.0 & 5.9 \\
\hline Main tenance sliop & 3 & 19,230 & 5.8 & 5.2 & 11.0 & 13.2 & 5.5 \\
\hline Office and sales & 2 & 1,404 & 7.3 & 4.0 & 11.3 & 11.6 & 9.5 \\
\hline Banquet and bar.- & 1 & 1,900 & 11.4 & 0.0 & 11.4 & & \\
\hline Storageforshipment & 2 & 8,380 & 14.3 & .0 & 14.3 & 30.0 & 8. 0 \\
\hline Storagc $\ldots \ldots$ & $1 \overline{1}$ & 80,575 & 15. 1 & 2. 1 & 17. 2 & 30.1 & 2.5 \\
\hline Sawing - . & 2 & 12,800 & 12.6 & 4.8 & 17.4 & 23.0 & 9.3 \\
\hline Drafting.- & 1 & 860 & 13.9 & 4. 0 & 17.9 & - &.- \\
\hline Woodworking. & 7 & 53,186 & 13.9 & 4. 1 & 18.0 & 28.5 & 11.3 \\
\hline Glue room & 2 & 15,600 & 14.3 & 5. 0 & 19.3 & 21.7 & 16.9 \\
\hline Leather room & 1 & 500 & 27.3 & 0.0 & 27.3 & & \\
\hline Lacquer vault .... & 2 & 1,660 & 53.3 & .0 & 53.3 & 73.0 & 33.6 \\
\hline Air-d̋rying building - & 1 & 10,200 & 59.4 & 4.0 & 63.4 & -- & $-\cdots$ \\
\hline Dry kilns _...... & 1 & 8,100 & 97.2 & 0.0 & 97.2 & -- & \\
\hline Vencer storage. & 1 & 2,100 & 117.3 & .0 & 117.3 & - &.- \\
\hline
\end{tabular}

a No entry indicates that only one area was used for tbat occupancy.

TaBle 7c. Percentage of furniture-factory floor having combustible contents within certain limits

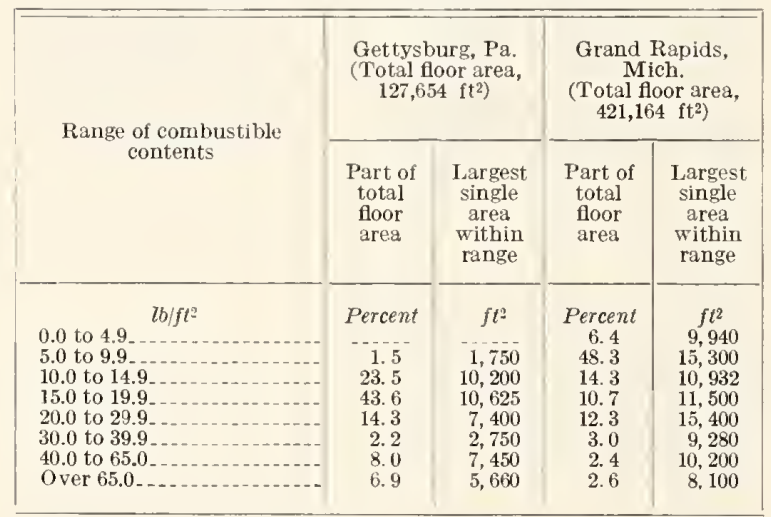

in Chicago, Ill. The Atlanta plant had 7 buildings of 1 or 2 stories. One of these, used for the assembly and storage of springs, was of reinforcedconcrete construction and the others were of masonry-wall, wood-joist, or all-metal construction. Temporary wood partitions and woodplank flooring covering parts of the area are included in the combustible contents.

The Chicago plant was housed in what was structurally one building with masonry exterior and subdividing walls, and interior wood or steel construction. The height for the different parts of the building ranged from 1 to 5 stories, with a. basement under all but the 1 - and 2 -story portions. There was maple flooring in all except basement, shop, and garnetting areas.

Table $8 \mathrm{c}$ gives a summary of combustibles within given ranges of concentration and the largest single area over which they were found, based upon the survey data given in tables $8 \mathrm{a}$ and $8 b$.

TABLE 8a. Survey data for mattress factory in Atlanta, Ga.

\begin{tabular}{|c|c|c|c|c|}
\hline \multirow[b]{2}{*}{ Occupancy or use } & \multirow[b]{2}{*}{ Area } & \multicolumn{3}{|c|}{ Combustible contents } \\
\hline & & $\begin{array}{l}\text { Mov- } \\
\text { able } \\
\text { prop- } \\
\text { crty } \\
\text { and } \\
\text { trim }\end{array}$ & Floor & Total \\
\hline \multicolumn{5}{|c|}{ Second floor, building 1} \\
\hline $\begin{array}{l}\text { Spring assembly } \\
\text { Spring storage } \\
\text { Spring assembly } \\
\text { Do } \\
\text { Lockers }\end{array}$ & $\begin{array}{r}f t^{2} \\
805 \\
900 \\
1,124 \\
453 \\
207\end{array}$ & $\begin{array}{r}2 b / f t^{2} \\
1.5 \\
0.0 \\
1.1 \\
3.5 \\
6.2\end{array}$ & $\begin{array}{r}l b / f t^{2} \\
0.0 \\
.0 \\
.0 \\
.0 \\
.0\end{array}$ & $\begin{array}{r}T b / f / 2 \\
1.5 \\
0.0 \\
1.1 \\
3.5 \\
6.2\end{array}$ \\
\hline $\begin{array}{l}\text { Total } \\
\text { Average }\end{array}$ & $\begin{array}{r}3,489 \\
-\ldots . .-\end{array}$ & 1.5 & 0.0 & $1 . \overline{5}$ \\
\hline
\end{tabular}

\begin{tabular}{|c|c|c|c|c|}
\hline \multicolumn{5}{|c|}{ Second floor, building 2} \\
\hline Temporary storage & 1,743 & 5.4 & 3.9 & 9.3 \\
\hline Cotton felt mattress. & 1.312 & 2.4 & 3.9 & 6.3 \\
\hline Mattress stapling. & 635 & 2.7 & 3.9 & 6.6 \\
\hline Mattress make-tup. & 635 & 1.7 & 3.9 & 5. 6 \\
\hline Mattress tape edging. & 942 & 3.9 & 3.9 & 7.8 \\
\hline Mattress button tufting & 1,243 & 2.9 & 3.9 & 6.8 \\
\hline Mattress reginning_... & 440 & 18.0 & 3.9 & 21.9 \\
\hline Spring receiving... & 472 & 8.3 & 3.9 & 12.2 \\
\hline Stapling - & 472 & 5.2 & 3.9 & 9.1 \\
\hline Cotton felt nuattress. & 864 & 4.9 & 3.9 & 8.8 \\
\hline Cotton tufting....... & 1,115 & 2.3 & 3.9 & 6.2 \\
\hline Roll edging... & 950 & 7.7 & 3.9 & 11.6 \\
\hline Temporarily unused. & 800 & 0.0 & 3.9 & 3.9 \\
\hline Total. & 11,623 & & & \\
\hline A verage & -..... & 4.1 & 3.9 & 8.0 \\
\hline
\end{tabular}

Second floor, building $2 \mathrm{~A}$

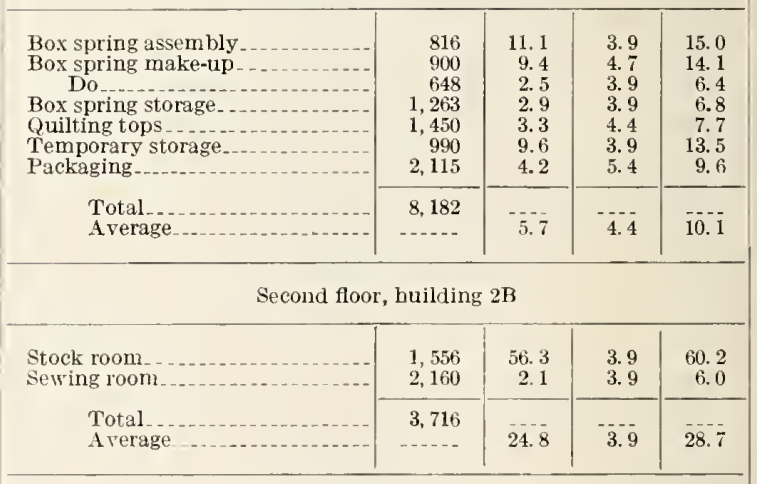

First floor, building 3

\begin{tabular}{|c|c|c|c|c|}
\hline $\begin{array}{l}\text { Cotton cleaner, picker } \\
\text { Cotton mixers } \\
\text { Cotton stores } \\
\text { Cotton batting, etc., stores }\end{array}$ & $\begin{array}{r}561 \\
1,080 \\
825 \\
6,170\end{array}$ & $\begin{array}{r}4.2 \\
0.6 \\
12.0 \\
15.4\end{array}$ & $\begin{array}{r}0.0 \\
.0 \\
.0 \\
.0\end{array}$ & $\begin{array}{r}4.2 \\
0.6 \\
12.0 \\
15.4\end{array}$ \\
\hline $\begin{array}{l}\text { Total_. } \\
\text { A rerage }\end{array}$ & $\begin{array}{r}8,636 \\
-\end{array}$ & 12.5 & 0.0 & 12.5 \\
\hline
\end{tabular}

Second floor, building 3

\begin{tabular}{|c|c|c|c|c|}
\hline $\begin{array}{l}\text { Garnetting } \\
\text { Do } \\
\text { Do } \\
\text { Fales }\end{array}$ & $\begin{array}{l}1,750 \\
2,816 \\
1,540 \\
1,853\end{array}$ & $\begin{array}{l}2.5 \\
2.6 \\
1.3 \\
3.1\end{array}$ & $\begin{array}{l}5.2 \\
5.2 \\
5.2 \\
5.2\end{array}$ & $\begin{array}{l}7.7 \\
7.8 \\
6.5 \\
8.3\end{array}$ \\
\hline $\begin{array}{l}\text { Total } \\
\text { A verage }\end{array}$ & 7,959 & 2.5 & 5. 2 & 7.7 \\
\hline
\end{tabular}


Table Sa. Survey data for mattress factory in Atlanta, Ga.Continued

\begin{tabular}{|c|c|c|c|c|}
\hline \multirow[b]{2}{*}{ Oceupancy or use } & \multirow[b]{2}{*}{ Area } & \multicolumn{3}{|c|}{ Combustible contents } \\
\hline & & $\begin{array}{l}\text { Mov- } \\
\text { able } \\
\text { prop- } \\
\text { erty } \\
\text { and } \\
\text { trim }\end{array}$ & Floor & Total \\
\hline \multicolumn{5}{|c|}{ Garnett annex, building 4} \\
\hline Garnett annes... & $\begin{array}{l}f t^{2} \\
4,810\end{array}$ & $\begin{array}{c}l b / f t^{2} \\
5.4\end{array}$ & $\begin{array}{c}l b / f t^{2} \\
0.0\end{array}$ & $\begin{array}{c}l b / f t^{2} \\
5.4\end{array}$ \\
\hline \multicolumn{5}{|c|}{ Cotton warehouse, building 5} \\
\hline Cotton warehouse & 8,010 & 101.3 & 0.0 & 101.3 \\
\hline \multicolumn{5}{|c|}{ Shipping, building 6} \\
\hline Shipping & 15.640 & 20.7 & 0.0 & 20.7 \\
\hline \multicolumn{5}{|c|}{ Garnett parts stores } \\
\hline Garnett parts stores & 740 & 15.8 & 0.0 & 15.8 \\
\hline
\end{tabular}

The difference found for the tir o plants was not great. Combustibles in amounts less than 10 $\mathrm{lb} / \mathrm{ft}^{2}$ were found in 48 percent of the area of one plant and in 66 percent of the area of the other, with the load uniformly distributed over areas as large as $7,310 \mathrm{ft}^{2}$. The combustible loads within the range of 10 to $20 \mathrm{lb} / \mathrm{ft}^{2}$ were 16.3 and 17.8 percent of the respective plant areas. Higher concentrations were largely in storage areas, with a baled-cotton-storage area having about 100 $\mathrm{lb} / \mathrm{ft}^{2}$. The progress of fire in such baled materials is relatively slow.

TABLE 8b. Survey data for mattress factory in Chicago, Ill.

\begin{tabular}{|c|c|c|c|c|}
\hline \multirow[b]{2}{*}{ Occupancy or use } & \multirow[b]{2}{*}{ Area } & \multicolumn{3}{|c|}{ Combustible contents } \\
\hline & & $\begin{array}{l}\text { Mov- } \\
\text { able } \\
\text { prop- } \\
\text { erty } \\
\text { and } \\
\text { trim }\end{array}$ & Floor & Total \\
\hline \multicolumn{5}{|c|}{ Basement } \\
\hline $\begin{array}{l}\text { Storage } \\
\text { Do } \\
\text { Do } \\
\text { Storage and hair conditioning }\end{array}$ & $\begin{array}{l}f t^{2} \\
3,881 \\
1,058 \\
3,144 \\
2,918\end{array}$ & $\begin{array}{l}l b / f t^{2} \\
28.0 \\
24.5 \\
19.0 \\
34.6 \\
\end{array}$ & $\begin{array}{c}l b / f f^{2} \\
0.0 \\
.0 \\
.0 \\
.0\end{array}$ & $\begin{array}{r}2 b / / t^{2} \\
25.0 \\
24.5 \\
19.0 \\
34.6\end{array}$ \\
\hline $\begin{array}{l}\text { Total_-_-- } \\
\text { A verage.- }\end{array}$ & 11,001 & 26.8 & 0.0 & 26.8 \\
\hline \multicolumn{5}{|c|}{ First floor } \\
\hline $\begin{array}{l}\text { Shipping } \\
\text { Do } \\
\text { Do } \\
\text { Do } \\
\text { Shop machine repairs.-. } \\
\text { Garnetting }\end{array}$ & $\begin{array}{l}3,017 \\
2,495 \\
4,783 \\
4,745 \\
1,620 \\
7,063\end{array}$ & $\begin{array}{l}4.5 \\
6.1 \\
8.4 \\
9.3 \\
4.1 \\
3.0\end{array}$ & $\begin{array}{l}2.6 \\
2.6 \\
2.6 \\
0.0 \\
.0 \\
.0\end{array}$ & $\begin{array}{r}7.1 \\
8.7 \\
11.0 \\
9.3 \\
4.1 \\
3.0\end{array}$ \\
\hline $\begin{array}{l}\text { Total } \\
\text { A verage }\end{array}$ & 23,723 & 6.0 & 1.1 & 7.1 \\
\hline
\end{tabular}

TABLE 8b. S'urvey data for mattress factory in Chicago, Ill.-Continued

\begin{tabular}{|c|c|c|c|c|}
\hline \multirow[b]{2}{*}{ Occupancy or use } & \multirow[b]{2}{*}{ Area } & \multicolumn{3}{|c|}{ Comrustible contents } \\
\hline & & $\begin{array}{l}\text { Moy- } \\
\text { able } \\
\text { prop- } \\
\text { erty } \\
\text { and } \\
\text { trim }\end{array}$ & Floor & Total \\
\hline \multicolumn{5}{|c|}{ Second floor } \\
\hline $\begin{array}{l}\text { Storage. } \\
\text { Do } \\
\text { Tufting and edging. } \\
\text { Tufting and storage }\end{array}$ & $\begin{array}{c}f t^{2} \\
3,801 \\
3,234 \\
7,310 \\
6,171\end{array}$ & $\begin{array}{c}l b / f t^{2} \\
6.0 \\
7.5 \\
3.7 \\
2.6\end{array}$ & $\begin{array}{r}l b / f t^{2} \\
2.6 \\
2.6 \\
2.6 \\
2.6\end{array}$ & $\begin{array}{r}l b / f t^{2} \\
8.6 \\
10.5 \\
6.3 \\
5.2\end{array}$ \\
\hline $\begin{array}{l}\text { Total } \\
\text { Average }\end{array}$ & 20,522 & 4.4 & $-\overline{2 .} 6$ & 7.0 \\
\hline \multicolumn{5}{|c|}{ Third floor } \\
\hline $\begin{array}{l}\text { Storage-cloth } \\
\text { Cloth inspection } \\
\text { Cloth storage. } \\
\text { Sewing } \\
\text { Do } \\
\text { Cutting cloth. } \\
\text { Repairing machines } \\
\text { Office } \\
\text { Filling mattresses }\end{array}$ & $\begin{array}{r}2,510 \\
460 \\
2,598 \\
1,681 \\
2,593 \\
4,355 \\
152 \\
135 \\
6,100\end{array}$ & $\begin{array}{r}19.2 \\
2.0 \\
22.7 \\
5.8 \\
4.9 \\
3.8 \\
19.7 \\
8.4 \\
7.3\end{array}$ & $\begin{array}{l}2.6 \\
2.6 \\
2.6 \\
2.6 \\
2.6 \\
2.6 \\
2.6 \\
2.6 \\
2.6\end{array}$ & $\begin{array}{r}21.8 \\
4.6 \\
25.3 \\
8.4 \\
7.5 \\
6.4 \\
22.3 \\
11.0 \\
9.9\end{array}$ \\
\hline $\begin{array}{l}\text { Total } \\
\text { Average. }\end{array}$ & 19,984 & $-\overline{9} \overline{6}$ & $-\overline{2 .}, \overline{6}$ & 12.2 \\
\hline \multicolumn{5}{|c|}{ Fourth floor } \\
\hline Boxing mattresses. & 1,860 & 13.8 & 2. 6 & 16.4 \\
\hline \multicolumn{5}{|c|}{ Firth floor } \\
\hline $\begin{array}{l}\text { Nailing box spring frames... } \\
\text { Assembling box spring frames. } \\
\text { Chair frames } \\
\text { Assembling beds } \\
\text { Painting } \\
\text { Box spring frames } \\
\text { Storage... } \\
\text { Do }\end{array}$ & $\begin{array}{r}235 \\
1,271 \\
460 \\
648 \\
1,222 \\
1,088 \\
456 \\
2,376\end{array}$ & $\begin{array}{r}9.9 \\
9.1 \\
9.5 \\
13.5 \\
3.9 \\
4.0 \\
4.1 \\
5.5\end{array}$ & $\begin{array}{l}2.6 \\
2.6 \\
2.6 \\
2.6 \\
2.6 \\
2.6 \\
2.6 \\
2.6\end{array}$ & $\begin{array}{l}\text { 12. } 5 \\
11.7 \\
12.1 \\
21.1 \\
\text { f. } 5 \\
\text { f. } 5 \\
6.7 \\
\text { 3. } 1\end{array}$ \\
\hline Total. & 7,756 & 7.0 & $2 . \overline{6}$ & $9 . \overline{6}$ \\
\hline
\end{tabular}

Table $8 \mathrm{~b}$ shows that the higher concentrations were found in basement areas, the highest arergge for floor's above the basement being $12.21 \mathrm{~b} \mathrm{ft}^{2}$. with the highest concentration for an individual area on these floors being $25.3 \mathrm{lb} / \mathrm{ft}^{2}$.

TABLE 8c. Percentage of maltress factory floor area hacing combustible contents within certain limits

\begin{tabular}{|c|c|c|c|c|}
\hline \multirow{2}{*}{$\begin{array}{l}\text { Range in combustible } \\
\text { contents }\end{array}$} & \multicolumn{2}{|c|}{$\begin{array}{l}\text { Chicago (Total floor } \\
\text { area, } \$ 4, \mathrm{St} \mathrm{ft}^{2} \text { ) }\end{array}$} & \multicolumn{2}{|c|}{$\begin{array}{l}\text { Atlanta (Total fluor } \\
\text { :area, }-2,0505 \mathrm{ft})\end{array}$} \\
\hline & $\begin{array}{c}\text { Part of } \\
\text { total floor } \\
\text { areas }\end{array}$ & $\begin{array}{c}\text { Largest } \\
\text { single } \\
\text { aresu with- } \\
\text { iu range }\end{array}$ & $\begin{array}{l}\text { Part of } \\
\text { total flow } \\
\text { arew }\end{array}$ & $\begin{array}{l}\text { Larpess } \\
\text { single } \\
\text { an's with- } \\
\text { in ramete }\end{array}$ \\
\hline 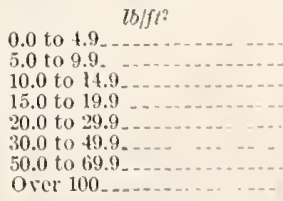 & $\begin{array}{c}\text { Percent } \\
10.5 \\
55.2 \\
11.0 \\
5.9 \\
12.5 \\
3.1 \\
\cdots\end{array}$ & 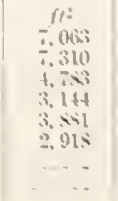 & 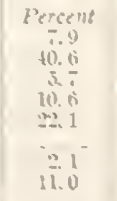 & 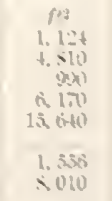 \\
\hline
\end{tabular}




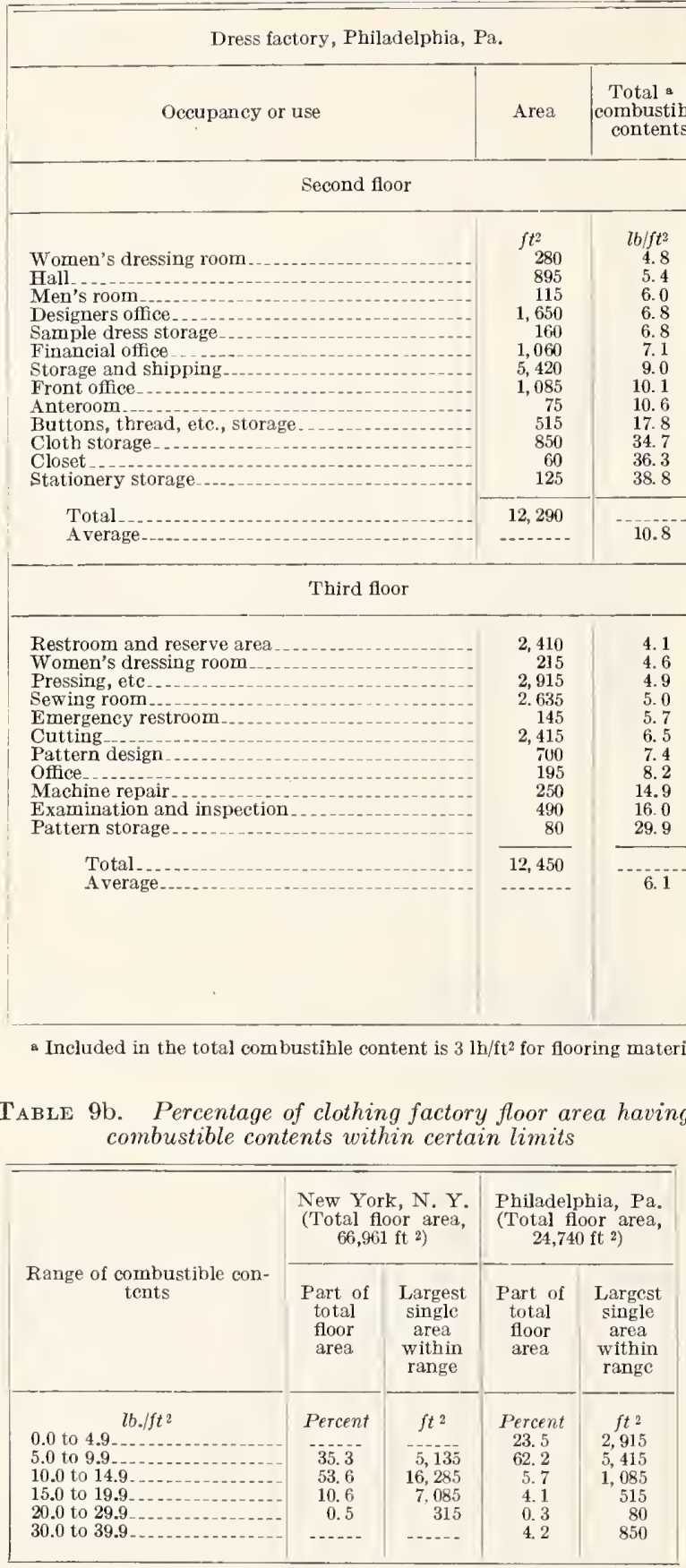

\section{c. Clothing Factories}

The factory making women's clothing occupied the second and third floors of a building 100 by 142 $\mathrm{ft}$ in outside dimensions. The men's clothing factory covered the fifth floor and part of the sixth floor in one building and part of the third floor in another building. The premises surveyed contained all operations from the receiving of the original bolt of cloth to the shipping of the finished goods.

The more detailed data of the two surveys are given in table $9 a$, and the summary of results is given in table $9 \mathrm{~b}$.

In the establishment making women's dresses, over 85 percent of the floor area had combustibles of no more than $10 \mathrm{lb} / \mathrm{ft}^{2}$. For the men's clothing factory, about 90 percent of the floor area had combustibles in the range 5 to $15 \mathrm{lb} / \mathrm{ft}^{2}$. For both establishments, heavier loadings were confined largely to storage areas, aggregating an average of nearly 10 percent of the floor area for the two plants. In all areas of both factories there was wood flooring with a computed weight of $3 \mathrm{lb} / \mathrm{ft}^{2}$.

\subsection{Printing Plants}

Of the two establishments surveyed, the one doing job printing exclusively was in five connected buildings built at different times as the plant expanded. They had two or three stories and basement and were of reinforced-concrete construction with floors designed for live load of 250 $\mathrm{lb} / \mathrm{ft}^{2}$.

The building for the newspaper plant, erected in 1922, had nine stories and basement, the in- 
terior construction being protected structural steel. It housed the printing plant and newspaper offices.

A summary of results grouped by ranges in combustible load is given in table 10c, and the data for individual areas are given in tables $10 \mathrm{a}$ and $10 \mathrm{~b}$.

TABLE 10a. Survey data for printing plant in Washington, D. C.

\begin{tabular}{|c|c|c|c|c|}
\hline \multirow[b]{2}{*}{ Occupancy or use } & \multirow[b]{2}{*}{ Area } & \multicolumn{3}{|c|}{ Combustible contents } \\
\hline & & $\begin{array}{l}\text { Mor- } \\
\text { able } \\
\text { prop- } \\
\text { erty } \\
\text { and } \\
\text { trim }\end{array}$ & Floor & Total \\
\hline \multicolumn{5}{|c|}{ Basement } \\
\hline $\begin{array}{l}\text { Paper storage } \\
\text { Record file room } \\
\text { Dead storage. } \\
\text { Oil storage. } \\
\text { Miscellaneous parts } \\
\text { Commercial stock room } \\
\text { Paper storage } \\
\text { Miscellaneous storage } \\
\text { Maintenance shop } \\
\text { Paper storage. } \\
\text { Do }\end{array}$ & $\begin{array}{r}f t^{2} \\
2,145 \\
355 \\
68 \\
288 \\
221 \\
3,994 \\
1,873 \\
576 \\
688 \\
8,840 \\
9,700\end{array}$ & $\begin{array}{r}7 b / f t^{2} \\
77.8 \\
70.9 \\
1.1 \\
72.7 \\
13.2 \\
53.1 \\
71.4 \\
13.9 \\
14.3 \\
146.6 \\
167.2\end{array}$ & $\begin{array}{c}l b / f t^{2} \\
-\cdots \\
-\cdots \\
-\cdots- \\
-\cdots \\
-\cdots \\
-\cdots \\
-\cdots \\
\cdots-- \\
-\cdots \\
-\cdots\end{array}$ & $\begin{array}{r}7 b / f t t^{2} \\
77.8 \\
70.9 \\
1.1 \\
72.7 \\
13.2 \\
53.1 \\
71.4 \\
13.9 \\
14.3 \\
146.6 \\
167.2\end{array}$ \\
\hline Trtal & 38,748 & 121.6 & $-\ldots$ & $1 \overline{21.6}$ \\
\hline \multicolumn{5}{|c|}{ First floor } \\
\hline $\begin{array}{l}\text { Private office } \\
\text { Reception office } \\
\text { Shipping office. } \\
\text { Commercial bindery } \\
\text { Do } \\
\text { Do } \\
\text { Sales office } \\
\text { Private office } \\
\text { Panel A } \\
\text { Panel B } \\
\text { Panel C } \\
\text { Panel D } \\
\text { Panel E } \\
\text { Commercial bindery }\end{array}$ & $\begin{array}{r}384 \\
476 \\
245 \\
4,916 \\
4,712 \\
3,698 \\
454 \\
240 \\
1,591 \\
1,924 \\
3,248 \\
549 \\
767 \\
9,250\end{array}$ & $\begin{array}{r}11.8 \\
8.2 \\
4.5 \\
14.0 \\
14.6 \\
18.4 \\
11.0 \\
8.6 \\
81.7 \\
14.7 \\
32.2 \\
28.8 \\
18.7 \\
52.4\end{array}$ & $\begin{array}{r}4.1 \\
4.0 \\
--- \\
--- \\
--. \\
4.0 \\
4.0 \\
-\cdots \\
-\cdots \\
--- \\
--- \\
-\cdots \\
-\cdots\end{array}$ & $\begin{array}{r}15.9 \\
12.2 \\
4.5 \\
14.0 \\
14.6 \\
18.4 \\
15.0 \\
12.6 \\
81.7 \\
14.7 \\
32.2 \\
28.8 \\
18.7 \\
52.4\end{array}$ \\
\hline Total & 32,454 & $30 . \overline{8}$ & 0.2 & 31.0 \\
\hline \multicolumn{5}{|c|}{ Second floor } \\
\hline $\begin{array}{l}\text { Accounting office } \\
\text { Office } \\
\text { Pressroom } \\
\text { Do } \\
\text { Do } \\
\text { Production office } \\
\text { Panel A } \\
\text { Panel B } \\
\text { Pressroom office } \\
\text { Panel A } \\
\text { Panel B } \\
\text { Roller room }\end{array}$ & $\begin{array}{r}747 \\
304 \\
5,137 \\
4,834 \\
5,233 \\
380 \\
3,200 \\
4,850 \\
438 \\
3,348 \\
5,624 \\
1,120\end{array}$ & $\begin{array}{r}8.1 \\
6.4 \\
11.7 \\
29.4 \\
15.3 \\
5.6 \\
40.0 \\
12.2 \\
11.3 \\
30.4 \\
14.5 \\
23.9\end{array}$ & $\begin{array}{r}1.0 \\
1.0 \\
-. .- \\
-1.0 \\
-0 \\
--. \\
4.0 \\
\cdots- \\
-.-\end{array}$ & $\begin{array}{r}9.1 \\
7.4 \\
11.7 \\
29.4 \\
15.3 \\
6.6 \\
40.0 \\
12.2 \\
15.3 \\
30.4 \\
14.5 \\
23.9\end{array}$ \\
\hline Total & 35,215 & 19.7 & 0.1 & 19.8 \\
\hline \multicolumn{5}{|c|}{ Third floor } \\
\hline $\begin{array}{l}\text { Composing room } \\
\text { Monotype department } \\
\text { Composing room } \\
\text { Proofreading room } \\
\text { Type storage room } \\
\text { Job-press department }\end{array}$ & $\begin{array}{r}4,477 \\
332 \\
2,650 \\
711 \\
767 \\
1,789\end{array}$ & $\begin{array}{r}6.6 \\
3.2 \\
4.9 \\
11.9 \\
12.8 \\
19.1\end{array}$ & 4.0 & $\begin{array}{r}6.6 \\
3.2 \\
4.9 \\
15.9 \\
12.8 \\
19.1\end{array}$ \\
\hline Total & 10,726 & $8 . \overline{9}$ & $0 . \overline{3}$ & 9.2 \\
\hline
\end{tabular}

TABLE 10b. Survey data for newspaper plant in Washington, D. C.

\begin{tabular}{|c|c|c|c|c|c|}
\hline \multirow[b]{2}{*}{ Occupancy or use } & \multirow[b]{2}{*}{ Area } & \multicolumn{4}{|c|}{ Combustible contents } \\
\hline & & $\begin{array}{l}\text { Mov- } \\
\text { able } \\
\text { prop- } \\
\text { erty }\end{array}$ & Floor & $\begin{array}{c}\text { Ex- } \\
\text { poserl } \\
\text { wood- } \\
\text { work } \\
\text { other } \\
\text { than } \\
\text { floor }\end{array}$ & Total \\
\hline \multicolumn{6}{|c|}{ Basement } \\
\hline $\begin{array}{l}\text { Basement } \\
\text { Locker room } \\
\text { Storeroom }\end{array}$ & $\begin{array}{r}f t^{2} \\
11,740 \\
409 \\
198\end{array}$ & $\begin{array}{c}\not b / f t^{2} \\
35.2 \\
2.3 \\
7.4\end{array}$ & $\begin{array}{c}l b / f t^{2} \\
\ldots- \\
\cdots-\end{array}$ & $\begin{array}{c}V_{1} / f t^{2} \\
\ldots \ldots \\
\ldots \ldots\end{array}$ & $\begin{array}{c}w_{b} / f t^{2} \\
35.2 \\
2.3 \\
7.4\end{array}$ \\
\hline $\begin{array}{l}\text { Total } \\
\text { Average }\end{array}$ & 12,347 & 33.7 & $\ldots$ & $\ldots$ & 33.7 \\
\hline
\end{tabular}

First floor

\begin{tabular}{|c|c|c|c|c|c|}
\hline Press room & 3,870 & 1.6 & 1.0 & & 2.6 \\
\hline Stereotype department.- & 648 & & 3. 2 & & 3.2 \\
\hline Office & 127 & 9.8 & $\ldots$ & 0.8 & 10.6 \\
\hline Oil room & 190 & 46.9 & $-\ldots$ & 1.3 & 48.2 \\
\hline Machine room & 426 & 10.7 & 5.0 & & 15.7 \\
\hline Newsstand................ & 228 & 8.1 & 2.6 & 5.0 & 15. 7 \\
\hline Corridor........... & 550 & $\ldots-$ & $-\ldots$ & 1.8 & 1.8 \\
\hline Total & 6,039 & & & & \\
\hline A verage........... & $--1-2$ & 3.7 & 1.5 & 0.4 & $5 . \overline{6}$ \\
\hline
\end{tabular}

Mezzanine floor

\begin{tabular}{|c|c|c|c|c|c|}
\hline $\begin{array}{l}\text { Delivery room } \\
\text { Offices_. } \\
\text { Corridor. }\end{array}$ & $\begin{array}{r}7,177 \\
865 \\
292\end{array}$ & $\begin{array}{r}10.8 \\
7.4 \\
13.1\end{array}$ & $\begin{array}{l}4.0 \\
2.6 \\
4.0\end{array}$ & $\begin{array}{l}0.3 \\
2.3 \\
2.2\end{array}$ & $\begin{array}{l}15.1 \\
12.3 \\
19.3\end{array}$ \\
\hline $\begin{array}{l}\text { Total } \\
\text { A verage }\end{array}$ & $\begin{array}{r}8,334 \\
-\end{array}$ & 10.5 & 3.9 & $0 . \overline{5}$ & 14.9 \\
\hline
\end{tabular}

Second floor

\begin{tabular}{|c|c|c|c|c|c|}
\hline Storeroom & 764 & 56.8 & 2. 6 & 0.2 & 59.6 \\
\hline Art department. & 511 & 5.5 & 6. 6 & 1. 6 & 13. 7 \\
\hline Darkroom & 149 & 3.8 & --- & 3.0 & 6.8 \\
\hline Etching department & 602 & 3.7 & & 1.5 & 5.2 \\
\hline Offices & 745 & 6.3 & 2. 6 & 2.9 & 11.8 \\
\hline office............... & 154 & 8.9 & 2.6 & 5.9 & 17.4 \\
\hline Workroom & 318 & 10.6 & 6. 6 & 2.5 & 19.7 \\
\hline Storeroom & 363 & 63.8 & 6. 6 & 2. 7 & 73.1 \\
\hline Service department & 1,082 & 6.2 & 2. 6 & 0.6 & 9.4 \\
\hline Machine room $\ldots \ldots \ldots$ & 2,549 & 2.9 & 2.5 & .8 & 6. 2 \\
\hline Corridor & 470 &.-- & --- & 2.5 & 2.5 \\
\hline Total & 7,707 & & & & \\
\hline Average... & .... & 12.4 & 2.8 & 1.4 & 16.6 \\
\hline
\end{tabular}

Third floor

\begin{tabular}{|c|c|c|c|c|c|}
\hline Associated Press. & 3,880 & 4. 1 & 3. 6 & 1.2 & S. 9 \\
\hline Wirephoto department. & 1,260 & 6.0 & 3. 6 & 2.5 & 12. $t$ \\
\hline Library & 231 & 18.9 & 3. 6 & 1.3 & 23.5 \\
\hline Offices_................... & 912 & 2.6 & 3.9 & 2.6 & 9.1 \\
\hline Storeroom & 190 & $7 \% .7$ & 1.6 & 3.4 & 527 \\
\hline Do $\ldots \ldots$ & 154 & t4. 9 & 2.6 & 2.8 & 50.3 \\
\hline Corridor.......... & 570 & $\ldots$ & $\ldots$ & 2.1 & 21 \\
\hline Total & $\pi, 19 \pi$ & & & & \\
\hline Average........... & 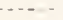 & & 3 & & \\
\hline
\end{tabular}

\begin{tabular}{|c|c|c|c|c|c|}
\hline \multicolumn{6}{|c|}{ Fourth floor } \\
\hline Storeroom. & 272 & 55.3 & 2.6 & 2.0 & (i). 5 \\
\hline Darkroom & $2: 2$ & 9.4 & 3.6 & 4. 1 & 16.1 \\
\hline Storeroom & 145 & 49.1 & 2.6 & 1.0 & 3i3. 3 \\
\hline Workroom . . . & 434 & 24.1 & 26 & 1.6 & $x .3$ \\
\hline Offices....... & 502 & 3.s & 6. 6 & 20 & $10, t$ \\
\hline Do & $6 \pi 1$ & 4. 1 & 3.4 & 3. 3 & 10,5 \\
\hline Do $\ldots \ldots \ldots$ & $2 \pi$ & 2.3 & 2.6 & 4. 1 & 9.0 \\
\hline$D_{0} \ldots$ & 390 & 5.0 & 26 & t. 5 & 121 \\
\hline Do $\ldots \ldots$ & (3) & $\therefore 9$ & 26 & 23 & 13.5 \\
\hline 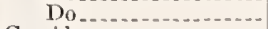 & 2,040 & 7.9 & 26 & 20 & 135 \\
\hline \multirow{3}{*}{ 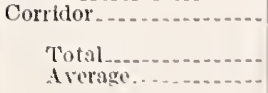 } & 1,577 & $\cdots$ & $\cdots$ & $3:$ & $2:$ \\
\hline & $\pi 16$ & & & & \\
\hline & $\ldots . .$. & 9.3 & 2.4 & $\therefore 9$ & 14.8 \\
\hline
\end{tabular}


TaBle 10b. Survey data for newspaper plant in Washington, D. C.-Continued

\begin{tabular}{|c|c|c|c|c|c|}
\hline \multirow[b]{2}{*}{ Occupancy or use } & \multirow[b]{2}{*}{ Area } & \multicolumn{4}{|c|}{ Combustible contents } \\
\hline & & $\begin{array}{l}\text { Mov- } \\
\text { able } \\
\text { prop- } \\
\text { erty }\end{array}$ & Floor & $\begin{array}{l}\text { Ex- } \\
\text { posed } \\
\text { wood- } \\
\text { work } \\
\text { other } \\
\text { than } \\
\text { floor }\end{array}$ & Total \\
\hline \multicolumn{6}{|c|}{ Fifth foor } \\
\hline 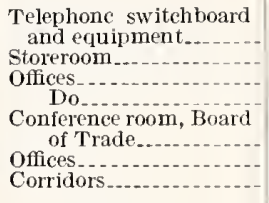 & $\begin{array}{r}\int t^{2} \\
520 \\
194 \\
447 \\
1,290 \\
1,294 \\
2,041 \\
1,348\end{array}$ & $\begin{array}{r}l b / f t^{2} \\
1.8 \\
39.1 \\
11.2 \\
10.3 \\
1.1 \\
5.4 \\
---.\end{array}$ & $\begin{array}{r}l b / f t^{2} \\
2.5 \\
2.6 \\
2.6 \\
2.6 \\
\\
2.6 \\
3.0 \\
-\cdots\end{array}$ & $\begin{array}{r}l b / f t^{2} \\
2.3 \\
2.6 \\
2.0 \\
3.4 \\
\\
1.0 \\
3.0 \\
3.1 \\
\end{array}$ & $\begin{array}{r}l b / f t^{2} \\
6.6 \\
44.3 \\
15.8 \\
16.3 \\
4.7 \\
11.4 \\
3.1 \\
\end{array}$ \\
\hline Total Average.......... & 7,134 & -6.1 & 2.2 & 2.0 & 10.3 \\
\hline \multicolumn{6}{|c|}{ Sixth floor } \\
\hline $\begin{array}{l}\text { Offices } \\
\text { Corridor } \\
\text { Lobby } \\
\text { Office. } \\
\text { Advertising and ac- } \\
\text { counting }\end{array}$ & $\begin{array}{r}1,786 \\
740 \\
371 \\
324 \\
\\
3,890\end{array}$ & $\begin{array}{l}7.0 \\
2.8 \\
0.0 \\
4.8 \\
7.4\end{array}$ & $\begin{array}{r}2.1 \\
-3.6 \\
6.6\end{array}$ & $\begin{array}{l}5.5 \\
3.1 \\
1.6 \\
5.1 \\
0.3\end{array}$ & $\begin{array}{r}14.6 \\
5.9 \\
1.6 \\
13.5 \\
14.3\end{array}$ \\
\hline Total & 7,111 & 6.3 & $4 . \overline{3}$ & 2.2 & 12.8 \\
\hline \multicolumn{6}{|c|}{ Seventh floor } \\
\hline $\begin{array}{l}\text { Office } \\
\text { Do } \\
\text { Art room } \\
\text { Photographers.. } \\
\text { Dental laboratory } \\
\text { City room } \\
\text { Corridor } \\
\text { Lobby }\end{array}$ & $\begin{array}{r}1,900 \\
140 \\
496 \\
439 \\
126 \\
3,446 \\
692 \\
371\end{array}$ & $\begin{array}{r}6.3 \\
31.2 \\
14.3 \\
6.2 \\
10.0 \\
3.6 \\
0.1 \\
---\end{array}$ & $\begin{array}{r}2.6 \\
2.6 \\
4.8 \\
--. \\
2.6 \\
6.6 \\
-\cdots \\
-\cdots\end{array}$ & $\begin{array}{l}4.0 \\
2.4 \\
1.1 \\
2.1 \\
1.2 \\
0.7 \\
3.5 \\
1.6\end{array}$ & $\begin{array}{r}12.9 \\
36.2 \\
20.2 \\
8.3 \\
13.8 \\
10.9 \\
3.6 \\
1.6\end{array}$ \\
\hline $\begin{array}{l}\text { Total } \\
\text { A verage }\end{array}$ & 7,610 & 5.2 & 4.1 & 1.9 & 11.2 \\
\hline \multicolumn{6}{|c|}{ Eighth floor } \\
\hline $\begin{array}{l}\text { Stereotype room } \\
\text { Composing room } \\
\text { Office... } \\
\text { Lobby. }\end{array}$ & $\begin{array}{r}1,296 \\
6,300 \\
54 \\
176\end{array}$ & $\begin{array}{r}0.7 \\
1.7 \\
7.6 \\
-\end{array}$ & $\begin{array}{r}3.2 \\
3.2 \\
-3.2\end{array}$ & $\begin{array}{r}0.5 \\
.3 \\
5.2 \\
1.6\end{array}$ & $\begin{array}{r}4.4 \\
5.2 \\
12.8 \\
4.8\end{array}$ \\
\hline $\begin{array}{l}\text { Total } \\
\text { A rerage }\end{array}$ & 7,826 & 1.5 & 3.2 & 0.4 & 5.1 \\
\hline \multicolumn{6}{|c|}{ Ninth floor } \\
\hline $\begin{array}{l}\text { Picture file room } \\
\text { Monotype room } \\
\text { Composing room A } \\
\text { Composing room B. } \\
\text { Office. } \\
\text { Storeroom } \\
\text { Office } \\
\text { Lobby } \\
\text { Locker room }\end{array}$ & $\begin{array}{r}914 \\
390 \\
1,600 \\
990 \\
232 \\
165 \\
54 \\
300 \\
1,494 \\
\end{array}$ & $\begin{array}{r}13.2 \\
0.9 \\
1.5 \\
0.9 \\
5.1 \\
11.1 \\
2.5 \\
0.0 \\
1.0\end{array}$ & $\begin{array}{l}\text { 3. } 2 \\
\text { 3. } 2 \\
\text { 3. } 2 \\
\text { 3. } 2 \\
\text { 3. } \\
\text { 3. } 2 \\
\text { 3. } 2 \\
4.0 \\
0.2\end{array}$ & $\begin{array}{l}0.4 \\
1.0 \\
0.1 \\
1.5 \\
1.7 \\
1.3 \\
5.1 \\
3.0 \\
-.--\end{array}$ & $\begin{array}{r}16.8 \\
5.1 \\
4.8 \\
5.6 \\
10.0 \\
15.6 \\
10.8 \\
7.0 \\
1.2\end{array}$ \\
\hline Total....... & 6,139 & 4.2 & 1.6 & 0.6 & 6.4 \\
\hline
\end{tabular}

For both buildings, combustibles of 10 to 20 $\mathrm{lb} / \mathrm{ft}^{2}$ covered about 40 percent of the floor area. A comparatively greater area in the newspaper plant had combustible contents of less than 10 $\mathrm{lb} / \mathrm{ft}^{2}$ because of the floor area occupied by equipment of incombustible type and the larger corridor areas. The higher loads in both plants were due to storage of paper before or after printing.
TABLE 10c. Percentage of printing plant floor areas having combustible contents within certain limits

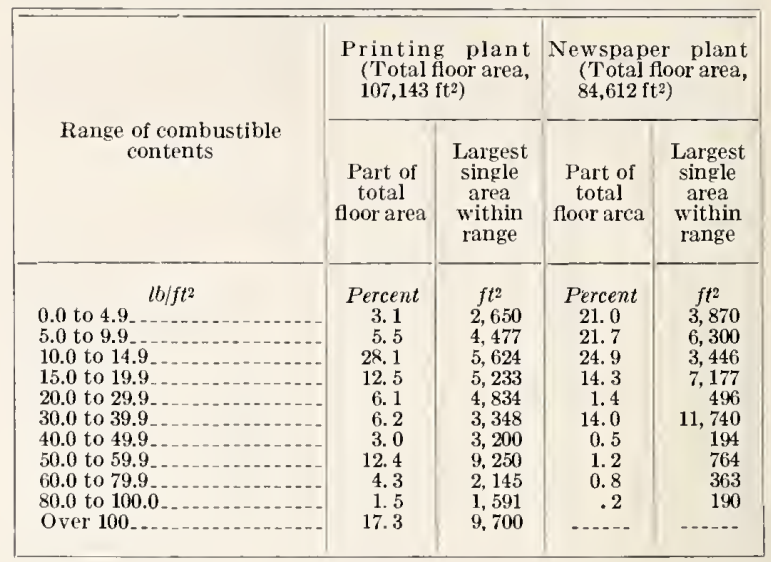

\subsection{Warehouses}

The five warehouses surveyed were of protectedsteel or reinforced-concrete construction and were from three to nine stories in height. Three of the buildings had basements. While five warehouses were surveyed, the more detailed survey data for only two, $W-4$ and $W-5$, are given in tables $11 \mathrm{a}$ and $11 \mathrm{~b}$. The percentage of the floor area, with combustible contents within a given range, and the largest single area over which the combustibles within these ranges were found for these two warehouses, are given in table 11c. Table 11d gives a complete summary of the combustible contents found in all five warehouses.

TABLE 11a. Survey data for warehouse W-4 in Washington, D. C.

\begin{tabular}{|c|c|c|c|c|}
\hline \multirow[b]{2}{*}{ Occupancy or use } & \multirow[b]{2}{*}{ Arca } & \multicolumn{3}{|c|}{ Combustible contents } \\
\hline & & $\begin{array}{l}\text { Mov- } \\
\text { able } \\
\text { prop- } \\
\text { erty }\end{array}$ & $\begin{array}{l}\text { Exposed } \\
\text { Wood- } \\
\text { work } \\
\text { other } \\
\text { than } \\
\text { floor }\end{array}$ & Total a \\
\hline \multicolumn{5}{|c|}{ Basement } \\
\hline $\begin{array}{l}\text { Switch board room } \\
\text { Locker room } \\
\text { Bascment storage }\end{array}$ & $\begin{array}{r}f t^{2} \\
358 \\
600 \\
4.569\end{array}$ & $\begin{array}{r}l b / f t^{2} \\
2.0 \\
2.2 \\
16.7\end{array}$ & $\begin{array}{c}t b / f t^{2} \\
3.6 \\
2.0 \\
0.3\end{array}$ & $\begin{array}{r}l b / f t^{2} \\
5.6 \\
4.2 \\
17.0\end{array}$ \\
\hline Total 1 verage & 5,527 & $14 . \overline{2}$ & 0.7 & 14.9 \\
\hline \multicolumn{5}{|c|}{ First floor } \\
\hline $\begin{array}{l}\text { Private officc. } \\
\text { General office } \\
\text { Vestibule. } \\
\text { Sales office... } \\
\text { Storage room A... } \\
\text { Warchouse, panels A to G, inclu- } \\
\text { sivc. }\end{array}$ & $\begin{array}{r}192 \\
1,167 \\
236 \\
653 \\
95 \\
4,697\end{array}$ & $\begin{array}{r}5.8 \\
6.3 \\
-7.6 \\
15.8 \\
7.4\end{array}$ & $\begin{array}{r}7.4 \\
1.5 \\
2.9 \\
3.0 \\
-1.6\end{array}$ & $\begin{array}{r}13.2 \\
7.8 \\
2.9 \\
10.6 \\
15.8 \\
11.2\end{array}$ \\
\hline $\begin{array}{l}\text { Total } \\
\text { A verage }\end{array}$ & 7,040 & 8.6 & 1.9 & 10.5 \\
\hline
\end{tabular}

See footnote at end of table. 
TABLE 11a. Survey data for warehouse W-4, in Washington, D. $\dot{C}$.-Continued

\begin{tabular}{|c|c|c|c|c|}
\hline \multirow[b]{2}{*}{ Occupancy or use } & \multirow[b]{2}{*}{ Area } & \multicolumn{3}{|c|}{ Combustible contents } \\
\hline & & $\begin{array}{l}\text { Mov- } \\
\text { able } \\
\text { prop- } \\
\text { erty }\end{array}$ & $\begin{array}{l}\text { Exposed } \\
\text { Wood- } \\
\text { work } \\
\text { other } \\
\text { than } \\
\text { floor }\end{array}$ & Total a \\
\hline \multicolumn{5}{|c|}{ Second floor } \\
\hline $\begin{array}{l}\text { Warehouse, panels } A-1, A-2, B \text {, } \\
\text { C, and D. }\end{array}$ & $\begin{array}{c}f t^{2} \\
8,916\end{array}$ & $\begin{array}{r}l b / f t^{2} \\
6.4\end{array}$ & $\begin{array}{r}l b / f t^{2} \\
0.5\end{array}$ & $\begin{array}{r}l b / f t^{2} \\
6.9\end{array}$ \\
\hline Total 1 rerage & 8,916 & 6.4 & $0 . \overline{5}$ & 6.9 \\
\hline \multicolumn{5}{|c|}{ Third floor } \\
\hline $\begin{array}{l}\text { Storeroom A } \\
\text { Warehouse, panels A to I, inclu- } \\
\text { sire. }\end{array}$ & $\begin{array}{r}95 \\
8.599\end{array}$ & $\begin{array}{r}6.6 \\
24.5\end{array}$ & 0.5 & $\begin{array}{r}6.6 \\
25.0\end{array}$ \\
\hline $\begin{array}{l}\text { Total } \\
\text { A verage }\end{array}$ & 8. 694 & $24 . \overline{6}$ & 0.5 & 25.1 \\
\hline \multicolumn{5}{|c|}{ Fourth floor } \\
\hline $\begin{array}{l}\text { Storeroom } \mathbf{A} \\
\text { Warehouse, panels } \mathbf{A}, \bar{B} \text {, and } \mathbf{C}\end{array}$ & $\begin{array}{r}95 \\
8,663\end{array}$ & $\begin{array}{l}41.1 \\
39.8\end{array}$ & $0 . \overline{5}$ & $\begin{array}{l}41.1 \\
40.3\end{array}$ \\
\hline $\begin{array}{l}\text { Total } \\
\text { A verage }\end{array}$ & $\begin{array}{l}8,758 \\
--2-\end{array}$ & 39.8 & 0.5 & $40 . \overline{3}$ \\
\hline \multicolumn{5}{|c|}{ Fifth floor } \\
\hline $\begin{array}{l}\text { Storeroom } \mathrm{B} \\
\text { Warehouse, panels } \mathrm{A} \text { and } \mathrm{B}\end{array}$ & $\begin{array}{r}650 \\
8,349\end{array}$ & $\begin{array}{r}42.3 \\
5.2\end{array}$ & $\begin{array}{r}0.8 \\
.4\end{array}$ & $\begin{array}{r}43.1 \\
8.0\end{array}$ \\
\hline Total & 8.999 & $-\overline{9} \overline{9}$ & 0.5 & $\overline{10 . \overline{6}}$ \\
\hline
\end{tabular}

TABLE 11a. Survey data for warehouse $W-4$ in Washington, D. C.-C'ontinued

\begin{tabular}{|c|c|c|c|c|}
\hline \multirow[b]{2}{*}{ Occupancy or use } & \multirow[b]{2}{*}{ Area } & \multicolumn{3}{|c|}{ Combustible contents } \\
\hline & & $\begin{array}{l}\text { Mov- } \\
\text { arle } \\
\text { prop- } \\
\text { erty }\end{array}$ & $\begin{array}{l}\text { Exposed } \\
\text { Wood- } \\
\text { work } \\
\text { other } \\
\text { than } \\
\text { floor }\end{array}$ & Totsl 3 \\
\hline \multicolumn{5}{|c|}{ Sixth floor } \\
\hline $\begin{array}{l}\text { Storeroom A } \\
\text { Storeroom B } \\
\text { Storeroom C } \\
\text { Warehouse, panels } \mathbf{A}, \mathbf{B} \text {, and } \mathbf{C}\end{array}$ & $\begin{array}{r}f t^{2} \\
95 \\
25.5 \\
518 \\
8.437\end{array}$ & $\begin{array}{l}(t) / f t^{2} \\
20.2 \\
31.7 \\
43.1 \\
13.0\end{array}$ & $\begin{array}{r}\psi_{3} / f t^{2} \\
-1.0 \\
0.8 \\
.5\end{array}$ & $\begin{array}{l}\not b / f t^{2} \\
20.2 \\
35.3 \\
43.5 \\
13.5\end{array}$ \\
\hline $\begin{array}{l}\text { Total } \\
\text { Average }\end{array}$ & 9,305 & 15.3 & $0 . \overline{5}$ & 15.9 \\
\hline \multicolumn{5}{|c|}{ Seventh floor } \\
\hline $\begin{array}{l}\text { Storeroom } \mathbf{A} \\
\text { Storeroom } \mathbf{B} \\
\text { Storeroom C } \\
\text { Warehouse, panels } \mathbf{A} \text { and } \mathbf{B}\end{array}$ & $\begin{array}{r}95 \\
184 \\
589 \\
8,437\end{array}$ & $\begin{array}{r}70.7 \\
6.6 \\
11.7 \\
27.0\end{array}$ & $\begin{array}{r}2.8 \\
0.9 \\
.6\end{array}$ & $\begin{array}{l}70.7 \\
12.0 \\
12.6 \\
27.6\end{array}$ \\
\hline Total & 9,305 & 26.1 & 0.6 & 26.8 \\
\hline \multicolumn{5}{|c|}{ Eighth floor } \\
\hline $\begin{array}{l}\text { Storeroom } \mathbf{A} \\
\text { Panel } \mathbf{B} \\
\text { Panels } \mathrm{A}-1, \overline{\mathrm{A}}-2, \mathrm{C} \text {. and } \mathbf{D}\end{array}$ & $\begin{array}{r}95 \\
4,287 \\
3,680\end{array}$ & $\begin{array}{r}18.8 \\
18.4 \\
5.7\end{array}$ & 0.4 & $\begin{array}{r}18.8 \\
18.8 \\
6.1\end{array}$ \\
\hline $\begin{array}{l}\text { Total_... } \\
\text { Average }\end{array}$ & 8,062 & 12.6 & 0.4 & 13.0 \\
\hline
\end{tabular}

a Where the total content is larger than the sum of the movable property and exposed woodwork, there was combustible flooring in that area that is included in the total.

TABLE 11b. Percentage of floor area of warehouse $\mathrm{W}-5$, New York, $N$. Y, having combustible contents within certain limits

\begin{tabular}{|c|c|c|c|c|c|c|c|c|c|c|}
\hline \multirow{2}{*}{ Range of combustible contents } & \multicolumn{10}{|c|}{ Floor } \\
\hline & Basement & First & Second & Third & Fourth & Fifth & Sixth & Seventh & Eightlı & Nintly \\
\hline $\begin{array}{l}0.0 \text { to } 9.9 \\
10.0 \text { to } 19.9 .9 \\
20.0 \text { to } 29.9 \\
30.0 \text { to } 39.9 \\
40.0 \text { to } 49.9\end{array}$ & $\begin{array}{r}\text { Percent } \\
5.2 \\
7.4 \\
-15.2 \\
14.9\end{array}$ & $\begin{array}{r}\text { Percent } \\
29.2 \\
14.8 \\
25.6 \\
6.7 \\
6.8\end{array}$ & $\begin{array}{r}\text { Percent } \\
10.5 \\
3.8 \\
3.3 \\
6.7 \\
15.6\end{array}$ & $\begin{array}{r}\text { Percent } \\
7.6 \\
6.7 \\
17.0 \\
3.4 \\
3.4\end{array}$ & $\begin{array}{r}\text { Percent } \\
-3.3 \\
13.5 \\
14.4 \\
20.4\end{array}$ & \begin{tabular}{c} 
Percent \\
\hdashline 3.4 \\
\hdashline 14.9
\end{tabular} & $\begin{array}{r}\text { Percent } \\
3.3 \\
3.3 \\
10.4 \\
21.4\end{array}$ & \begin{tabular}{c} 
Percent \\
-3.4 \\
$-\cdots$ \\
\hdashline$-\cdots$
\end{tabular} & $\begin{array}{r}\text { Percent } \\
13.5 \\
7.0 \\
6.8 \\
18.3\end{array}$ & $\begin{array}{l}\text { Percent } \\
0 \\
0 . . \\
10.2 \\
10.1\end{array}$ \\
\hline $\begin{array}{l}50.0 \text { to } 74.9 \\
75.0 \text { to } 99.99 \\
100.0 \text { to } 149.9 \\
150.0 \text { to } 199.9 \\
200.0 \text { to } 256.6\end{array}$ & $\begin{array}{r}44.3 \\
9.3 \\
3.7 \\
- \\
-\end{array}$ & \begin{tabular}{r}
10.1 \\
6.8 \\
\hdashline-- \\
$-1 .-$
\end{tabular} & $\begin{array}{r}29.5 \\
20.4 \\
6.8 \\
3.4 \\
-\end{array}$ & $\begin{array}{r}29.7 \\
6.7 \\
22.1 \\
3.4\end{array}$ & $\begin{array}{r}29.2 \\
8.0 \\
11.2 \\
- \\
-\end{array}$ & $\begin{array}{r}39.6 \\
25.2 \\
6.7 \\
10.2\end{array}$ & $\begin{array}{r}29.1 \\
25.6 \\
6.9 \\
-\end{array}$ & $\begin{array}{l}23.7 \\
10.1 \\
15.3 \\
20.7 \\
15.8\end{array}$ & \begin{tabular}{r}
26.1 \\
24.9 \\
3.4 \\
\hdashline$\ldots$ \\
\end{tabular} & $\begin{array}{r}40.3 \\
20.3 \\
4.5 \\
7.6 \\
\end{array}$ \\
\hline Total area & 10,806 & 11,848 & 11,848 & 11,848 & 11.848 & 11,848 & 11.848 & 11,848 & 11., Na & 11.945 \\
\hline
\end{tabular}

The contents of warehouse $W-1$, for a large printing establishment, were largely stored paper in rolls, paper cartons, or wooden crates. The flooring over most of the area was either 2-in. asphalt paving blocks, assumed to have (in terms of wood) equivalent combustible weight of 6.2 $\mathrm{lb} / \mathrm{ft}^{2}$, or $2 \frac{1}{2}-\mathrm{in}$. end-grain hard pine blocks weighing $10 \mathrm{lb} / \mathrm{ft}^{2}$. Part of the area of the third floor $\left(10,225 \mathrm{ft}^{2}\right)$ was depressed for railroad tracks on which there were 14 freight cars with paper contents aggregating $630,000 \mathrm{lb}$.
Warehouses $W-2$ and $\mathbb{W}-3$ served department stores, with a large part of the storage consisting of clothing, furniture, floor corerings, paint, toys wrapping paper, and cartons. 'The tirst floor of warehouse $I T-3$ was used only for merehindise in transit and there was none on the floor at the time of the surver.

Warehonse IT-4, near railrosel terminals, carried incoming stocks of merchandise for locint dealess. A percentage of the area, varying from thore to floor, was without load at the time of the surver. 
TABLE 11c. Percentage of storage-building floor areas having combustible contents within certain limits

\begin{tabular}{|c|c|c|c|c|}
\hline \multirow{2}{*}{$\begin{array}{l}\text { Range of combustible } \\
\text { contents }\end{array}$} & \multicolumn{2}{|c|}{$\begin{array}{c}\text { Washington, W-4 } \\
\text { (Total floor area, } \\
74,606 \mathrm{ft}^{2} \text { ) }\end{array}$} & \multicolumn{2}{|c|}{$\begin{array}{l}\text { New York, W-5 (Total } \\
\left.\text { floor area, } 117,170 \mathrm{ft}^{2}\right)\end{array}$} \\
\hline & $\begin{array}{l}\text { Part of } \\
\text { total } \\
\text { floor area }\end{array}$ & $\begin{array}{l}\text { Largest } \\
\text { single } \\
\text { area } \\
\text { within } \\
\text { range }\end{array}$ & $\begin{array}{l}\text { Part of } \\
\text { total } \\
\text { floor area }\end{array}$ & $\begin{array}{l}\text { Largest single } \\
\text { area within } \\
\text { range }\end{array}$ \\
\hline $\begin{array}{l}l b / f t^{2} \\
0.0 \text { to } 4.9 \\
5.0 \text { to } 9.9 \\
10.0 \text { to } 14.9 \\
15.0 \text { to } 19.9 \\
20.0 \text { to } 29.9\end{array}$ & $\begin{array}{c}\text { Percent } \\
1.1 \\
30.3 \\
19.8 \\
12.1 \\
23.0\end{array}$ & $\begin{array}{r}f t^{2} \\
600 \\
8,916 \\
8,437 \\
4,569 \\
8,599\end{array}$ & $\begin{array}{l}\text { Percent } \\
3.7 \\
2.9 \\
2.7 \\
2.2 \\
\quad 6.6\end{array}$ & Survey units \\
\hline $\begin{array}{l}30.0 \text { to } 39.9 \\
40.0 \text { to } 49.9 \\
50.0 \text { to } 59.9 \\
60.0 \text { to } 70.7 \\
50.0 \text { to } 74.9\end{array}$ & $\begin{array}{r}0.3 \\
13.3 \\
-0.1 \\
-0\end{array}$ & $\begin{array}{r}255 \\
8,663 \\
-95 \\
-\end{array}$ & \begin{tabular}{c}
8.0 \\
12.7 \\
\hdashline 30.2
\end{tabular} & $\begin{array}{l}\text { bays with } \\
\text { areas from } \\
396 \text { to } 560 \\
\mathrm{ft}^{2} \text {. }\end{array}$ \\
\hline $\begin{array}{l}75.0 \text { to } 99.9 \\
100.0 \text { to } 149.9 \\
150.0 \text { to } 199.9 \\
200.0 \text { to } 256.6\end{array}$ & 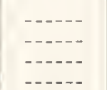 & n-n & $\begin{array}{r}15.7 \\
8.3 \\
5.0 \\
2.0\end{array}$ & \\
\hline
\end{tabular}

and the difference in the average load for the individual floors is as much attributable to this condition as to differences in concentrations for areas carrying load. Even for those floors carrying loads over nearly the whole area (4th, 5th, and 7 th), a considerable range in average load was found.

Warehouse W-5 carried storage for a number of clients, and the types of goods stored covered a wide range. A plan of the sixth floor, which carried a load near the average for the warehouse, is shown in figure 3 . The combustibles present were almost wholly in the goods stored and, hence, only the total combustibles represented thereby are given in table $11 \mathrm{~d}$ for each floor. The averageload variation between floors, as also between panels on a floor, was large.

For warehouse W-4, about one-half of the floor area had combustible concentrations no higher than $15 \mathrm{lb} / \mathrm{ft}^{2}$ and for almost all of the remaining area they were not over $50 \mathrm{lb} / \mathrm{ft}^{2}$. For warehouse W-5, nearly 18 percent of the floor area had combustible load of less than $30 \mathrm{lb} / \mathrm{ft}^{2}$, about 50 percent carried between 30 and $75 \mathrm{lb} / \mathrm{ft}^{2}, 24$ percent carried 75 to $150 \mathrm{lb} / \mathrm{ft}^{2}$, and 7 percent had greater combustible load.

\subsection{Offices}

The office surveys include areas in buildings that house offices, or spaces directly associated therewith, and office spaces found in the surveys of other occupancies. The survey data for all office areas is given in table $12 \mathrm{a}$.

The range of combustibles found in offices in the various other occupancies, with the exception of the newspaper plant, was about the same as that of the offices, office and reception rooms, and office and light-file areas in buildings housing office occupancies. The former ranged from 4.5 to $15.9 \mathrm{lb} / \mathrm{ft}^{2}$, as compared to 3.8 to $16.7 \mathrm{lb} / \mathrm{ft}^{2}$ for the latter. Law offices and law libraries gave
TABLE 11d. Summary data for warehouses

\begin{tabular}{|c|c|c|c|c|c|}
\hline \multirow[b]{2}{*}{ Portion of building } & \multirow[b]{2}{*}{$\begin{array}{l}\text { Floor } \\
\text { area }\end{array}$} & \multicolumn{4}{|c|}{ Combustible contents } \\
\hline & & $\begin{array}{l}\text { Movable } \\
\text { property }\end{array}$ & Floor & $\begin{array}{c}\text { Exposed } \\
\text { wood- } \\
\text { work } \\
\text { other } \\
\text { than floor }\end{array}$ & Total \\
\hline \multicolumn{6}{|c|}{ Survey $W-1$} \\
\hline $\begin{array}{l}\text { Basement } \\
\text { 1st floor } \\
\text { 2d floor-- } \\
\text { 3d floor } \\
\text { 3d floor- } \\
\text { 3d-floor total }\end{array}$ & $\begin{array}{c}f t^{2} \\
33,890 \\
34,900 \\
32,592 \\
23,448 \\
10,225 \\
33,673\end{array}$ & $\begin{array}{r}l b / f t^{2} \\
172.9 \\
223.7 \\
105.8 \\
204.0 \\
61.6 \\
160.8\end{array}$ & $\begin{array}{r}t b / f t^{2} \\
6.2 \\
9.7 \\
10.0 \\
6.2 \\
0.0 \\
4.3\end{array}$ & $\begin{array}{c}l b / f t^{2} \\
0.0 \\
.0 \\
.4 \\
.0 \\
.0 \\
.0\end{array}$ & $\begin{array}{r}l b / f t^{2} \\
179.1 \\
233.4 \\
116.2 \\
210.2 \\
61.6 \\
165.1\end{array}$ \\
\hline Entire building - & 135,055 & 166.8 & 7.5 & 0.1 & 174.4 \\
\hline \multicolumn{6}{|c|}{ Survey $\mathrm{W}-2$} \\
\hline 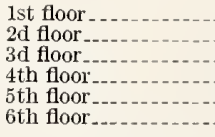 & $\begin{array}{l}46,158 \\
44,957 \\
45,677 \\
45,677 \\
45,677 \\
45,677\end{array}$ & $\begin{array}{r}6.8 \\
13.6 \\
4.0 \\
12.7 \\
8.4 \\
12.2\end{array}$ & $\begin{array}{l}0.0 \\
.0 \\
.0 \\
.0 \\
.0 \\
.0\end{array}$ & $\begin{array}{l}0.0 \\
1.0 \\
1.2 \\
2.2 \\
1.9 \\
3.8\end{array}$ & $\begin{array}{r}6.8 \\
14.6 \\
5.2 \\
14.9 \\
10.3 \\
16.0\end{array}$ \\
\hline Entire building. & 273,823 & 9.6 & 0.0 & 1.5 & 11.1 \\
\hline \multicolumn{6}{|c|}{ Survey $\mathrm{W}-3$} \\
\hline $\begin{array}{l}\text { 1st floor } \\
\text { 2d floor } \\
\text { 3d floor } \\
\text { 4th floor }\end{array}$ & $\begin{array}{l}17,442 \\
17,442 \\
17,442 \\
17,442\end{array}$ & $\begin{array}{r}0.0 \\
16.2 \\
16.0 \\
10.6\end{array}$ & $\begin{array}{l}0.0 \\
.0 \\
.0 \\
.0\end{array}$ & $\begin{array}{l}0.0 \\
.8 \\
2.3 \\
2.1\end{array}$ & $\begin{array}{r}0.0 \\
17.0 \\
18.3 \\
12.7\end{array}$ \\
\hline Entire building. . & a. 52,326 & 14.3 & 0.0 & 1.7 & 16.0 \\
\hline \multicolumn{6}{|c|}{ Survey $W_{-4}$} \\
\hline 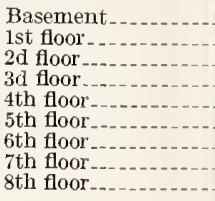 & $\begin{array}{l}5,527 \\
7,040 \\
8,916 \\
8,694 \\
8,758 \\
8,999 \\
9,305 \\
9,305 \\
8,062\end{array}$ & $\begin{array}{r}14.2 \\
8.6 \\
6.4 \\
24.6 \\
39.8 \\
7.9 \\
15.3 \\
26.1 \\
12.6\end{array}$ & $\begin{array}{r}0.0 \\
.0 \\
.0 \\
.0 \\
.0 \\
2.2 \\
0.1 \\
.1 \\
.0\end{array}$ & $\begin{array}{l}0.7 \\
1.9 \\
0.5 \\
.5 \\
.5 \\
.5 \\
.5 \\
.6 \\
.4\end{array}$ & $\begin{array}{r}14.9 \\
10.5 \\
6.9 \\
25.1 \\
40.3 \\
10.6 \\
15.9 \\
26.8 \\
13.0\end{array}$ \\
\hline Entire building. & 74,606 & 17.2 & 0.2 & 0.7 & 18.1 \\
\hline \multicolumn{6}{|c|}{ Survey W-5 } \\
\hline $\begin{array}{l}\text { Basement } \\
\text { 1st floor } \\
\text { 2d floor } \\
\text { 3d floor } \\
\text { 4th floor } \\
\text { 5th floor } \\
\text { 6th floor } \\
\text { 7th floor } \\
\text { 8th floor } \\
\text { 9th floor }\end{array}$ & $\begin{array}{l}10,806 \\
11,848 \\
11,848 \\
11,848 \\
11,848 \\
11,848 \\
11,848 \\
11,848 \\
11,848 \\
11,848\end{array}$ & 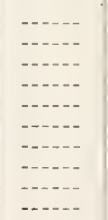 & 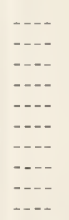 & 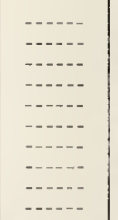 & $\begin{array}{r}50.0 \\
27.8 \\
62.5 \\
65.9 \\
54.0 \\
80.6 \\
62.2 \\
133.3 \\
52.9 \\
70.3\end{array}$ \\
\hline Entire building. - & 117,438 & 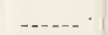 &.-- &.---- & 65.9 \\
\hline
\end{tabular}

a Not including the first floor, which was used only for merchandise in transit.

loads in the range 17.9 to $35.3 \mathrm{lb} / \mathrm{ft}^{2}$. For heavy filing, the range was from 28.1 to $85.9 \mathrm{lb} / \mathrm{ft}^{2}$.

In table $12 \mathrm{~b}$ are given the total area, percent of total area, and largest single area, having combustible load within given ranges. It is seen that a little less than 70 percent of the total office area surveyed had combustible load of less than 20 $\mathrm{lb} / \mathrm{ft}^{2}$, about 28 percent had 20 to $40 \mathrm{lb} / \mathrm{ft}^{2}$, and in only a relatively small part was the load over $40 \mathrm{lb} / \mathrm{ft}^{2}$. 
TABLE 12a. Survey data of offices and offices associated with other occupancies

\begin{tabular}{|c|c|c|c|c|c|c|c|}
\hline \multirow{3}{*}{ Occupancy or use } & \multirow{3}{*}{$\begin{array}{l}\text { Vum- } \\
\text { ber of } \\
\text { offices } \\
\text { sur- } \\
\text { resed }\end{array}$} & \multirow{3}{*}{$\begin{array}{l}\text { Total } \\
\text { floor } \\
\text { area }\end{array}$} & \multicolumn{5}{|c|}{ A rerage combustible contents } \\
\hline & & & \multirow{2}{*}{$\begin{array}{l}\text { Mor- } \\
\text { able } \\
\text { prop- } \\
\text { erty } \\
\text { and } \\
\text { trim }\end{array}$} & \multirow[b]{2}{*}{ Floor } & \multicolumn{3}{|c|}{ Total } \\
\hline & & & & & $\begin{array}{l}\text { Arer- } \\
\text { age }\end{array}$ & $\begin{array}{l}\text { Maxi- } \\
\text { mum }\end{array}$ & $\begin{array}{l}\text { Mini- } \\
\text { mum }\end{array}$ \\
\hline $\begin{array}{l}\text { Office building: } \\
\text { Office only }\end{array}$ & 2 & $\begin{array}{l}f t^{2} \\
407\end{array}$ & $\begin{array}{c}l b / f t^{2} \\
5,9\end{array}$ & $\begin{array}{c}2 b / f t^{2} \\
23\end{array}$ & $\begin{array}{r}l b / f t^{2} \\
8,2\end{array}$ & $7 b / 5 t^{2}$ & $u_{3} / f^{2}$ \\
\hline Office and recep- & & & & & & & \\
\hline Office and light & 20 & 581 & 4.9 & 1. 7 & 6.6 & 8.8 & 4. 3 \\
\hline files das Hont & 20 & 11,800 & 8.0 & 0.8 & 8.8 & 16.7 & 3.8 \\
\hline Heary files .. & 9 & $2 \%, 431$ & 35.7 & .2 & 35.9 & 85.9 & 28.1 \\
\hline Law office.... & 2 & 556 & 18.5 & --- & 18.5 & 19. 6 & 17.9 \\
\hline Law library.-- & 2 & 2,992 & 17.2 & 0.1 & 17.3 & 35.3 & 19.7 \\
\hline Offices in: & & & & & & & \\
\hline Departmen: stores & 2 & 11,230 & 5.9 & .7 & 6.6 & 6.9 & 6.4 \\
\hline Furniture factories. & 3 & 1,534 & 7.1 & 4.1 & 11. 2 & 11.6 & 9.7 \\
\hline Printing plant..... & 9 & 3,668 & 8.6 & 2. 6 & 11.2 & 15.9 & 4.5 \\
\hline Jewspaper plant.. & 22 & 19,479 & 9.7 & 3.5 & 13. 2 & 36.2 & 8.9 \\
\hline Dress factory ......- & 4 & 3,990 & 4.8 & 3. 0 & 7.8 & 10.1 & 6.8 \\
\hline $\begin{array}{l}\text { Wen's clothmg tac- } \\
\text { tory }\end{array}$ & 2 & 3,335 & 7.9 & 3.0 & 10.9 & 10.9 & 10.6 \\
\hline Warehouse & 3 & 2,012 & 10.5 & $-\ldots$ & 10.5 & 13.2 & 7.8 \\
\hline
\end{tabular}

TABLE 12b. Percentage of the floor areas of offices and offices associated with other occupancies having combustible contents within certain limits

\begin{tabular}{|c|c|c|c|}
\hline Range of combustible contents & $\begin{array}{c}\text { Area } \\
\text { within } \\
\text { range }\end{array}$ & $\begin{array}{l}\text { Total } \\
\text { area } \\
\text { within } \\
\text { range }\end{array}$ & $\begin{array}{l}\text { Largest } \\
\text { single } \\
\text { area } \\
\text { within } \\
\text { range }\end{array}$ \\
\hline $\begin{array}{l}0.0 \text { to } 9.9 \\
10.0 \text { to } 14.9 \\
15.0 \text { to } 19.9 \\
20.0 \text { to } 29.9 \\
30.0 \text { to } 39.9 \\
40.0 \text { to } 85.9\end{array}$ & $\begin{array}{r}f t^{2} \\
27,242 \\
24,844 \\
7,961 \\
9,031 \\
15,877 \\
3,122\end{array}$ & $\begin{array}{l}\text { Percent } \\
31.0 \\
28.2 \\
9.0 \\
10.2 \\
18.0 \\
3.6\end{array}$ & $\begin{array}{l}f t^{2} \\
7,230 \\
3,890 \\
2,533 \\
7,742 \\
9,550 \\
2,041\end{array}$ \\
\hline
\end{tabular}

\section{General Notes and Summary}

The results of the surveys show that there is a correlation between some of the occupancies and combustible loading. In other occupancies, such as manufacturing and storage, there is much variation, depending on the classes of materials involved and the operational plans of the establishments.

In large areas within fire walls or fire partitions, the fire exposure to the floor construction above from a fire in the contents would vary to an extent with the concentrations of combustibles on the floor beneath.

\subsection{Residential Occupancies}

Combustible loadings of 13 to $14 \mathrm{lb} / \mathrm{ft}^{2}$ were found in limited areas in dwellings and a concentration of $49.3 \mathrm{lb} / \mathrm{ft}^{2}$ was found in a linen closet. However, the greatest average for a whole dwelling unit did not exceed $10 \mathrm{lb} / \mathrm{ft}^{2}$, and in view of the fact that there were no subdividing fire walls, the average combustible load $\left(10 \mathrm{lb} / \mathrm{ft}^{2}\right)$ appears to be a reasonable value. The six apartmenthouse storage rooms, at the time surveyed, had no greater combustible load than the highest average for dwelling units as a whole.

\subsection{Hospitals}

Three buildings, each housing a different hospital activity, were surveyed at a large institution. A total of 469 rooms or units having an aggregate area of $143,780 \mathrm{ft}^{2}$ was surveyed.

The group averages of combustible contents for patients' rooms, dormitories, waiting rooms, corridors, kitchens, and dining rooms ranged from 0.8 to $3.9 \mathrm{lb} / \mathrm{ft}^{2}$, with no single area or unit exceeding $5.2 \mathrm{lb} / \mathrm{ft}^{2}$. The range of the group averages for administrative, doctors', attendants', and nurses' offices and rooms was from 2.9 to $8.6 \mathrm{lb} / \mathrm{ft}^{2}$. with a maximum for an individual area of 14.4 $\mathrm{lb} / \mathrm{ft}^{2}$. In service areas, including storerooms, laundries, and janitors' closets, the averages ranged from 0.5 to $13.1 \mathrm{lb} / \mathrm{ft}^{2}$, with an individual maximum of $23 \mathrm{lb} / \mathrm{ft}^{2}$. Loadings in the range of 0.2 to $21.6 \mathrm{lb} / \mathrm{ft}^{2}$ were found in individual areas used for treatment, surgery, and clinics.

The lower combustible loads were found in the comparatively large ward, dormitory, and patientroom areas rather than in office, service, and operational areas.

\subsection{Schools}

The surveys indicate that in classrooms, laboratories, library reading rooms, and similar areas the combustible contents did not exceed $15 \mathrm{lb} / \mathrm{ft}^{2}$. Library stackrooms, storerooms, and offices, represcnting a small percentage of the total area, had higher combustible loads.

\subsection{Mercantile Establishments}

Combustible loads below $20 \mathrm{lb} / \mathrm{ft}^{2}$ were found in all but 3.8 percent of the area surveved in the New York department store, and in all but 5.0 percent of the area in the Washington department store. The higher combustible loads were, generally, from sales stocks and stock storage not effectively segregated from the other areas. In view of the large open areas and the small proportion containing the higher combustible loads. it appears that the effect of these loads on the general fire severity would be ninor.

\subsection{Manufacturing Establishments}

The range of combustible contents in manufacturing plants is large, depending to a great extent on the goods made. The results of the presint surveys should be helpful in giving information on the combustible loads to be cxpected in the types of plants surveyed or in those that are similar.

The buildings housing the higher combustible loads were seldom of heights or areas requiring so-called "fully fire-resistive" construction, slthough such construction might be justified from 
the standpoint of the owner and the decrease in hazard to nearby property.

The combustible contents in the clothing factories surveyed were less than $20 \mathrm{lb} / \mathrm{ft}^{2}$ for all but a small percentage of the area. Such occupancy does not represent an excessive potential fire severity for buildings of fire-resistive construction.

\subsection{Printing Establishments}

The newspaper plant surveyed contained a combustible load of $30 \mathrm{lb} / \mathrm{ft}^{2}$ or over on only 16.7 percent of the area. The printing plant carried a combustible load of $30 \mathrm{lb} / \mathrm{ft}^{2}$ or more on 44.7 percent of the floor arca. The higher load in each case was caused by storage of paper and combustible supplies.

\subsection{Warehouses}

The contents of storage buildings surveyed covered a wide range in type and distribution of the combustible materials housed.

For the two department store warehouses and the one carrying incoming stocks for local dealers, the combustible loads were within the range where structural protection for the possible fire severity can be provided without resort to unusual building details.

The high combustible loads in the warehouse for a big printing establishment were largely of paper in tight rolls or packages. After the initial stage of a fire in such contents, the intensity decreases, allowing more ready approach for extinguishment. In the absence of extinguishment, such storages will be fully consumed, and the required structural protection against the resulting fire severity is beyond presently defined means of attainment.

The general-storage warehouse, $W-5$, carried combustible loads up to $75 \mathrm{lb} / \mathrm{ft}^{2}$ on nearly 70 percent of its area. Combustibles on the remaining area ranged up to $256.5 \mathrm{lb} / \mathrm{ft}^{2}$ for an individual floor bay and to $133.3 \mathrm{lb} / \mathrm{ft}^{2}$ for an entire floor. Combustible loads below $30 \mathrm{lb} / \mathrm{ft}^{2}$ occupied only 18.1 percent of the building, and only 1 floor of the 10 had such a low average.

\subsection{Office Occupancies}

No surveys were made covering all parts of office buildings; however, surveys were made of typical areas in six such buildings, and of office areas in a number of other occupancies. In office areas, including light files, the combustibles exceeded $20 \mathrm{lb} / \mathrm{ft}^{2}$ only in a small office of the newspaper plant where it amounted to 36.2 $\mathrm{lb} / \mathrm{ft}^{2}$ on an area of $140 \mathrm{ft}^{2}$. The fire severity resulting from this concentration would be reduced by the lower combustible load in large adjacent areas averaging less than $15 \mathrm{lb} / \mathrm{ft}^{2}$.

In areas used for heavy files, the combustible contents ranged from 28.1 to $85.9 \mathrm{lb} / \mathrm{ft}^{2}$. In law libraries, combustible loads as high as 35.3 $\mathrm{lb} / \mathrm{ft}^{2}$ were found.

\section{General Objective and Application}

The data from the present surveys present a general view of the combustible contents associated with typical buildings and occupancies. In conjunction with information from fire-severity tests and fires in buildings, data from these surveys can be applied in connection with requirements for minimum fire resistance of buildings, such as in building codes. Beyond such minimum requirements, building designers and owners can apply the data to provide a degree of structural protection that will prevent collapse of the structurc from fires in contents. Where such structural protection cannot be fully attained, it can be supplemented with built-in fire-extinguishing equipment.

Although buildings may be seriously damaged by a fire of severity approaching that for which their structural protection is designed, prevention of major collapse is important in decreasing the possibility of spread of fire to adjacent construction and in affording a safer approach for fire extinguishment. Conflagrations have been stopped on a line of such fire-resistive buildings and, although fire was communicated to those immediately exposed, such buildings gave the needed protection to buildings beyond them.

\section{References}

[1] Fire-rcsistance classifications of building constructions, NBS Building Materials and Structures Report (1942), BMS92.

[2] S. H. Ingberg, The severity of building fires, Proc. 14th Annual Meeting Building Officials Conference of America, 87-97 (1928); Safety Eng. 56, 57-61 and 103-106 (1928); Quart. Nat. Fire Protect. Assoc. 22, 43-61 (1928); Arch. Forum 50, 775 (1929).

[3] Standard methods of fire tests of building construction and materials, American Society for Testing Materials, Designation E119-54.

[4] Post war building studies No. 20 (1946), Fire grading of buildings, part 1, General principles and structural precautions, by a Joint Committee of the Building Research Board of the Department of Scientific and Industrial Research and the Fire Offices Committee; published for the Ministry of Public Works, H. M. Stationery Office, London.

[5] International Critical Tables 5, 162-169 (1929).

[6] Handbook of fire protection of the National Fire Protection Association, 11th Ed., 1460-1461 (1954). 

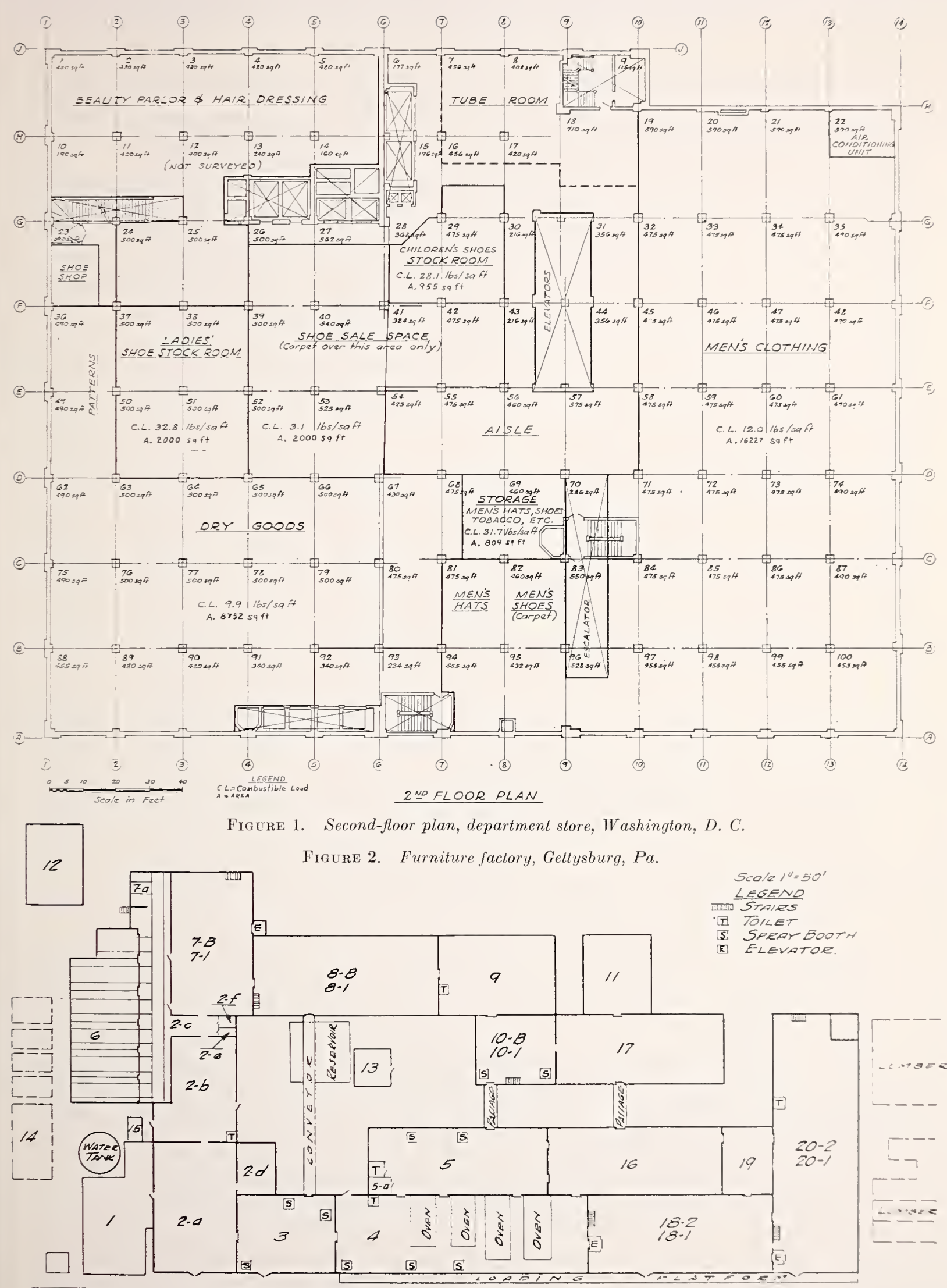

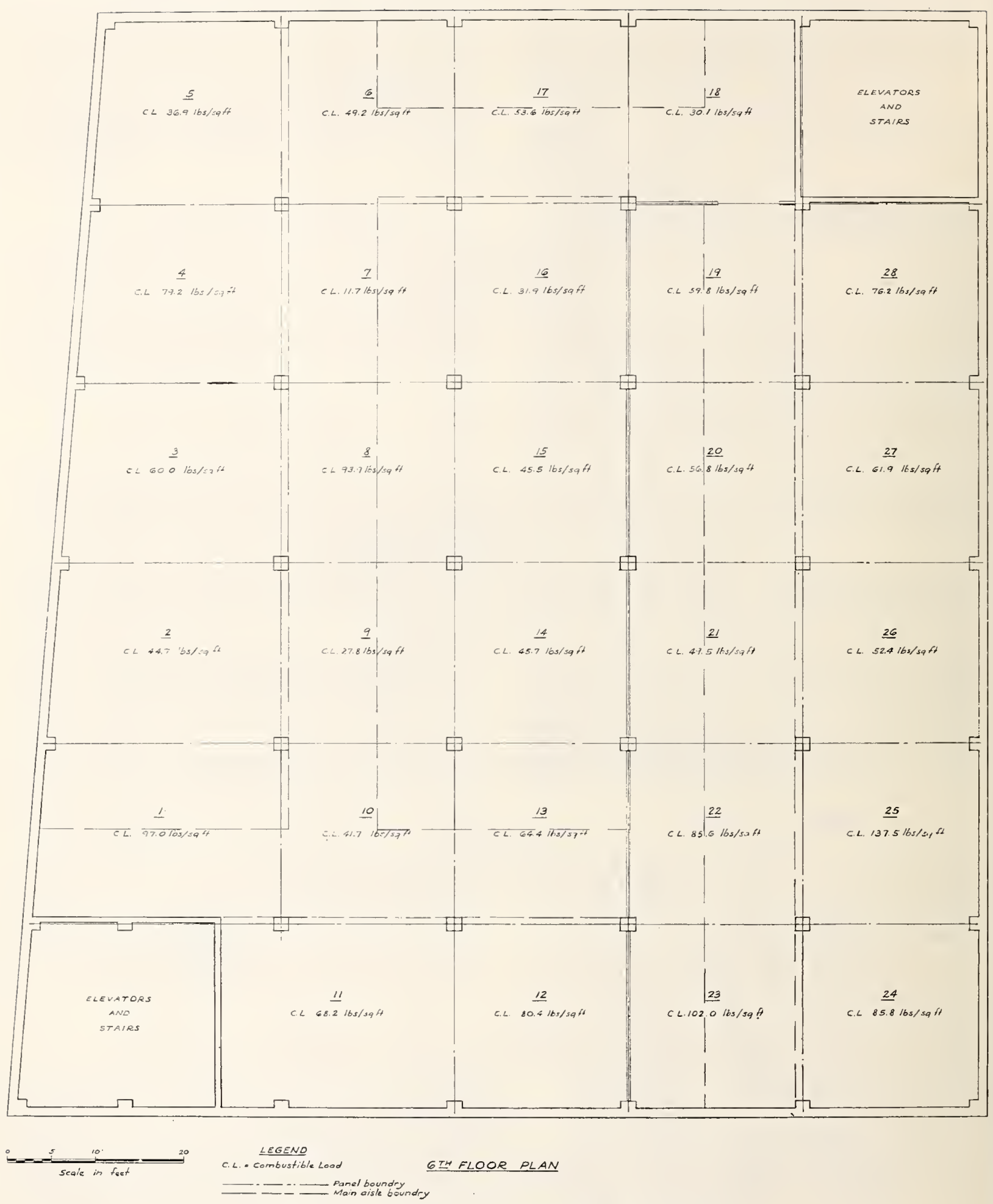

Figure 3. Sixth-floor plan, warehouse, New York, N. Y.

Washington, December 5, 1956. 
[Continued from cover page II]

BMIS37

BuIS38

BMS39

BMS40

BMS41

BMIS42

BMS43

B.IS44

BMS40

BMS46

BMS47

BMIS48

B.IS49

BMIS50

BMISō1

BMIS52

BMS55 3

BMS54

BMIS55

BMS56

BMS57

BMIS58

BMS509

BMS60

BגIS61

BMS62

BMIS63

BMS64

BMIS65

BMS66

BMS67

BMS68

BMS69

BMS70

BMIS71

BMS72

BMS73

BMS74

BMS75

BMS76

BMS77

BMS78

BMS79

BMS80

BMIS81

BMS82

BMS83

BMS84

BMS85

BMS86

BMS87

- Out of print.
Structural Properties of "Palisade Homes" Constructions for Walls, Partitions, and Floors Sponsored by Palisade Homes

Structural Properties of Two "Dunstone" Wall Constructions Sponsored by the W. E. Dunn Manufacturing Co

Structural Properties of a Wall Construction of "Pfeifer Units" Sponsored by the Wisconsin Units Co a

Structural Properties of a Wall Construction of "Knap Concrete Wall Units" Sponsored by Knap America, Inc

Effect of Heating and Cooling on the Permeability of Masonry Walls

Structural Properties of Wood-Frame Wall and Partition Construction with "Celotex" Insulating Boards Sponsored by The Celotex Corporation

Performance Test of Floor Coverings for Use in Low-Cost Housing: Part 2

Surface Treatment of Steel Prior to Painting

Air Infiltration Through Windows.

Structural Properties of "Scott-Bilt" Prefabricated Sheet-Steel Construction for Walls, Floors, and Roofs Sponsored by The Globe-TWernicke Co

Structural Properties of Prefabricated Wood-Frame Constructions for Walls, Partitions, and Floors Sponsored by American Houses, Inc

Structural Properties of "Precision-Built" Frame Wall and Partition Constructions Sponsored by the Homasote Co.

Metallic Roofing for Low-Cost House Construction

Stability of Fiber Building Boards as Determined by Accelerated Aging.-.....-

Structural Properties of "Tilecrete Type A" Floor Construction Sponsored by the Tilecrete Co

Effect of Ceiling Insulation Upon Summer Comfort Sponsored by the Munlock Engineering Co $\mathrm{Co}$

Effect of Soot on the Rating of an Oil-Fired Heating Boiler

Effects of Wetting and Drying on the Permeability of Masonry Walls.

A Survey of Humidities in Residences

Roofing in the United States-Results of a Questionnaire

Properties of Adhesives for Floor Coverings

Strength, Absorption, and Resistance to Laboratory Freezing and Thawing of Building Bricks Produced in the United States.

Structural Properties of Two Nonreinforced Monolithic Concrete Wall Constructions.-

Structural Properties of a Precast Joist Concrete Floor Construction Sponsored by the Portland Cement Association.

Ioisture Condensation in Building Walls

Solar Heating of Various Surfaces

Methods of Estimating Loads in Plumbing Systems

Plumbing Manual Partitions, Floors, and Roofs, Sponsored by Herman A. Mugler.......

Performance Test for Floor Coverings for Use in Low-Cost Housing: Part 3 . - . - -

Stability of Fiber Sheathing Boards as Determined by Accelerated Aging-.-.-...-

Asphalt-Prepared Roll Roofings and Shingles . . .

Fire Tests of Wood- and Metal-Framed Partitions struction Sponsored by the Homasote Co...

Indentation Characteristics of Floor Coverings

Structural and Heat-Transfer Properties of "U. S. S. Panelbilt" Prefabricated Sheet-
Steel Constructions for Walls, Partitions, and Roofs Sponsored by the Tennessee Coal, Iron \& Railroad Co

Survey of Roofing Materials in the North Central States

Effect of Outdoor Exposure on the Water Permeability of Masonry Walls........

Properties and Performance of Fiber Tile Boards Constructions

Water-Distributing Systems for Buildings

Performance Test of Floor Coverings for Use in Low-Cost Housing: Part 4-..-

Field Inspectors' Check List for Building Constructions (cloth cover $5 \times 71 / 2$ inches) -- -

Water Permeability of Walls Built of Masonry Units

Strength of Sleeve Joints in Copper Tubing Made With Various Lead-Base Solders.--

Survey of Roofing Materials in the South Central States.-
Dimensional Changes of Floor Coverings With Changes in Relative Humidity and

Temperature Construction Sponsored by the General Shale Products Corporation - . ......-

A Method for Developing Specifications for Building Construction-Report of Subcommittee on Specifications of the Central Housing Committee on Research, Design, and Construction.

[List continued on cover page IV]

\section{$10 \%$}

108 


\section{BUILDING MATERIALS AND STRUC'TURES REPORTS}

\section{[Continued from cover page IrI]}

BMS88 Recommended Building Code Requirements for New Dwelling Construction With Special Reference to War Housing

BMS89 Structural Properties of "Precision-Built, Jr." (Second Construction) Prefabricated Wood-Frame Wall Construction Sponsored by the Homasote Co . P

BMS90 Structural Properties of "PHC" Prefabricated Wood-Frame Constructions for Walls, Floors, and Roofs Sponsored by the PHC Housing Corporation........

BMS91

BMS92

BMS93

BMS94

BMS95

BMS96

BMS97

BMS98

BMS99

BMS100

BMS101

BMS102

BMS103

BMS104

BMS105

BMS106

BMS107

BMS108

BMS109

BMS110

BMS111

BMS112

A Glossary of Housing Terms

Fire-Resistance Classifications of Building Constructions Accumulation of Moisture in Walls of Frame Construction During Winter Exposure Water Permeability and Weathering Resistance of Stucco-Faced, Gunite-Faced, and "Knap Concrete-Unit" Walls.

Tests of Cement-Water Paints and Other Waterproofings for Unit-Masonry Walls...

Properties of a Porous Concrete of Cement and Uniform-Sized Gravel

Experimental Dry-Wall Construction With Fiber Insulating Board

Physical Properties of Terrazzo Aggregates

Structural and Heat-Transfer Properties of "Multiple Box-Girder Plywood Panels" for

Walls, Floors, and Roofs

Relative Slipperiness of Floor and Deck Surfaces

Strength and Resistance to Corrosion of Ties for Cavity Walls.

Painting Steel-_..

Measurements of Heat Losses From Slab Floors

Structural Properties of Prefabricated Plywood Lightweight Constructions for Walls, Partitions, Floors, and Roofs Sponsored by the Douglas Fir Plywood Association.-

Paint Manual with particular reference to Federal Specifications_._.

Laboratory Observations of Condensation in Wall Specimens_-_._.

Building Code Requirements for New Dwelling Construction

Temperature Distribution in a Test Bungalow With Various Heating Devices.-...-..

Strength of Houses: Application of Engineering Principles to Structural Design

Paints for Exterior Masonry Walls

Performance of a Coal-Fired Boiler Converted to Oil

Properties of Some Lightweight-Aggregate Coneretes With and Without an AirEntraining Admixture

BMS113

BMS114

BMS115

BMS116

BMS117

BMS118

BMS119

BMS120

BMS121

BMS122

BMS123

BMS124

BMS125

BMS126

BMS127

BMS128

BMS129

BMS130

BMS131

BMS132

BMS133

BMS134

BMS135

BMS136

BMS137

Fire Resistance of Structural Clay Tile Partitions

Temperature in a Test Bungalow With Some Radiant and Jacketed Space Heaters

Preparation and Revision of Building Codes. . . .

Fire Resistance of Walls of Lightweight Aggregate Concrete Masonry Units

Stack Venting of Plumbing Fixtures

Wet Venting of Plumbing Fixtures

Fire Resistance of Walls of Gravel-Aggregate Concrete Masonry Units.

Investigation of Failures of White-Coat Plasters

Physical Properties of Some Samples of Asbestos-Cement Siding-

Fire Tests of Wood-Framed Walls and Partitions With Asbestos-Cement Facings.--.-

Fire Tests of Steel Columns Protected With Siliceous Aggregate Concrete

Stone Exposure Test Wall

The Self-Siphonage of Fixture Traps

Effect of Aging on the Soundness of Regularly Hydrated Dolomitic Lime Putties.-.

Atmospheric Exposure Tests of Nailed Sheet Metal Building Materials .............

Fire Endurance of Shutters for Moving-Stairway Openings _.

Methods and Equipment for Testing Printed-Enamel Felt-Base Floor Covering

Fire Tests of Gunite Slabs and Partitions.

Capacities of Plumbing Stacks in Buildings.-.

Live Loads on Floors in Buildings ......

Fire Resistance of Concrete Floors

Fire Tests of Steel Columns Encased With Gypsum Lath and Plaster.

Properties of Cavity Walls . _ _...

Influence of the Wash From Bronze on the Weathering of Marble

Effect of Edge Insulation Upon Temperature and Condensation on Concrete-Slab Floors

BMS139

BMS140

BMS141

Studies of Stone-Setting Mortars

Second Edition, Selected Bibliography on Building Construction and Maintenance.-.-

Fire Endurance of Open-Web Steel Joist Floors With Concrete Slabs and Gypsum Ceilings . -

BMS142

BMS143

Frost Closure of Roof Vents

Fire Tests of Brick Walls

Sound Insulation of Wall and Floor Constructions

Supplement to BMS144, Sound Insulation of Wall, Floor, and Door Constructions - -

BMS145

BMS146

BMS147

BMS148

Fire Effects and Fire Control in Nitrocellulose Photographic-Film Storage.

Plasticity and Water Retentivity of Hydrated Limes for Structural Purposes of Mineral Additives on the Durability of Coating-Grade Roofing Asphalts ..-

BMS149

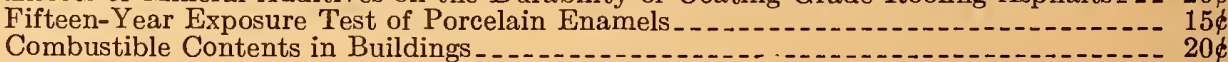

"Out of print. 